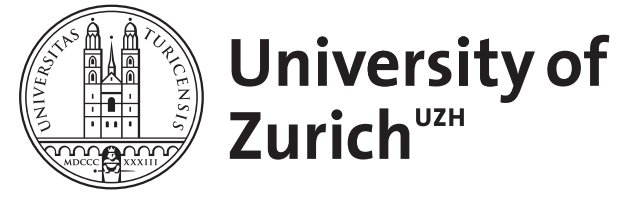

Zurich Open Repository and Archive

University of Zurich

University Library

Strickhofstrasse 39

CH-8057 Zurich

www.zora.uzh.ch

Year: 2018

'Monosyllabism' and some other perennial clichés about the nature, origins and contacts of the Chinese language in Europe

Behr, Wolfgang

Posted at the Zurich Open Repository and Archive, University of Zurich

ZORA URL: https://doi.org/10.5167/uzh-161613

Book Section

Published Version

Originally published at:

Behr, Wolfgang (2018). 'Monosyllabism' and some other perennial clichés about the nature, origins and contacts of the Chinese language in Europe. In: Malinar, Angelika; Müller, Simone. Asia and Europe Interconnected: Agents, Concepts, and Things. Wiesbaden: Harrassowitz, 155-209. 


\title{
"Monosyllabism" and Some Other Perennial Clichés About the Nature, Origins and Contacts of the Chinese Language in Europe ${ }^{1}$
}

\author{
Wolfgang Behr
}

\section{Introduction}

The question of what differentiates or unites Europe and Asia - geographically, culturally, anthropologically - was already convoluted in European antiquity. In the late

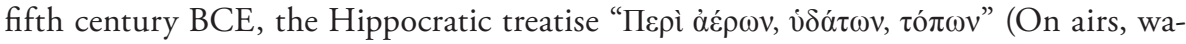
ters and places) tried to address the issue by sketching a kind of "ecodeterministic" Völkerpsychologie of all known Eurasian peoples for the first time. ${ }^{2}$ The author, traditionally believed to be the famous Greek physician Hippocrates (c. 460-377 BCE) himself, is still confident in chapter XII that the inhabitants of Asia and Europe "differ from each

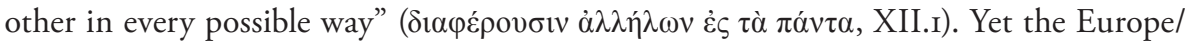
Asia distinction becomes increasingly blurred in his later chapters, before it is finally fully eclipsed by an alternative Greek/Barbarian antithesis in chapter XIV (Backhaus 1976). Moreover, throughout antiquity the twofold division into Asia - often only referring to "Asia minor" - and Europe had a complicated and shifting relationship with the third space called "Libya", i.e. Africa (Schubert 200o), just as it does today. While nearly all of today's $90+$ countries of "Eurasia" 3 sit on one shared tectonic plate, the boundaries of Europe and Asia continue to be disputed. Whether it is in school atlases opened on different sides of the Ural or the Bosphorus Strait, in country lists of international organizations, or for the purposes of the European song contest - the exact extensions of "Europe" and "Asia" remain unclear. As unclear, one hastens to add, as the origins of the goddess of half-Semitic extraction which probably gave Europe its name (West 1997: 45I; Beekes \& van Beek 20IO: 483-484).

1 For useful comments on an earlier draft of this article, the author wishes to thank Christoph Harbsmeier (Oslo), Elisabeth Kaske (Leipzig), Dinu Luca (Taipei), Matthias Richter (Colorado), Mårten Söderblom-Saarela (Berlin), Hartmut Walravens (Berlin), Jeroen Wiedenhof (Leiden) and the editors of this volume.

2 See for a recent edition Jouanna (1996), for the dating Craik (20I5: II). The English translation by Francis Adams (I796-I87I) is available from the MIT classics archive at http://classics.mit.edu// Hippocrates/airwatpl.html (last visited 28.05.2018).

3 Another term with a complicated history and lots of political overtones. For a selection of the pertinent literature, see Behr (2000/200I: 356-357). 
Today, the contiguous landmass of Eurasia is home to some 24 genealogically independent language families, comprising almost 1500 living languages, and a dozen linguistic isolates like Basque or Burushaski. ${ }^{4}$ If language is any indicator of cohesion, Eurasia is highly fragmented and was, if anything, even more so during the various Asian and European antiquities. ${ }^{5}$ Moreover, at least since the beginnings of bronze technology and horse domestication in Eurasia, contact must have been frequent and intense within and across language families in many areas.

Unlike in Ancient Greece, constructions of ethnic identity in China rarely relied upon linguistic criteria before the consolidation of the empire under the Western Han emperor Wudi 武帝 (I56-I87) (Behr 2004, 20I0; Pines 2005; Kim 2009). True to their Greek predecessors, on the other hand, European intellectuals were quick to integrate the scant available information about the languages and writing systems of East Asia in early Christian missionary accounts since the sixteenth century into wide-ranging cultural, religious and political attempts at self-demarcation. While the history of China as a target of European "othering" can be traced to medieval times (Reichert I992; Münkler 2000), nourished by the scattered information brought "home" by transcontinental travelers under the Mongol empire, it has been tied to continuously changing intellectual agendas, political constellations and religious conflicts ever since. Invariably, European authors had to navigate between tensions arising from competing Biblical vs. Asian chronologies, universalist vs. culturalist ethics and diffusionist vs. genealogical models of emergence. The role of "exotic" Asian languages or of non-alphabetic writing systems in such debates was by no means fixed. What could be seen as a deficiency during one period, e.g. the apparent need to rely on "non-phonological" writing to compensate for the rampant homophonicity characteristic of phonologically reduced and grammatically isolating spoken languages, could be reinterpreted as an asset by authors of another period, interested in universal "philosophical" communication, unbound by the fetters of morphology and phonology-specific scripts.

The present essay will look at one aspect of this tangle of forces - the genesis of linguistically motivated strategies of self-assurance vis-à-vis China in post-Enlightenment Europe. Focusing on eighteenth and nineteenth century discourses about remote relationships of languages, on (mis)construals of the Chinese writing system, and on the debates contrasting the alleged monosyllabic nature of Classical Chinese with IndoEuropean inflectional morphology, I will also try to show how entrenched linguistic alterity tropes survived well into the modern and contemporary periods. The examples of Jacques Lacan (I9OI-I98I), Roland Barthes (I9I5-I980) or Jacques Derrida (I930-2004) which will be held against the canvas of earlier colonial period philosophers and linguists as we go along, clearly show how more or less subconscious longue durée continuities of Chinese language related arguments continue to be indelibly woven into the writings of

4 See http://glottolog.org/glottolog/family (last visited 28.05.2018).

5 Extrapolating from what is currently assumed about the stability of language and rates of language death, Bickel (2OI4: I2O n. 5) calculates that there must have been half a million languages since the emergence of human language some $100 \mathrm{k}$ years ago. 
otherwise radically "post-colonial" authors. Despite the dramatic increase of available information and factual entanglements between Asia and Europe, the negative perception of China consolidated by German idealism in the aftermath of Hegel's (I770-I83I) philosophy of history and religion, serves like a "ghost in the discourse machine". It continues to haunt modern authors even where putative East-West differences are construed relativistically, couched in positively connotated exoticisms or when they are marketed as "decentered" perspectives and argumentative vantage points.

Irrespective of questions of origins or cultural implications, sophisticated tools exist today to analyze the relationship between linguistic features and geographical distributions in Eurasia. A massive collaborative work like the World Atlas of Language Structures (Dryer \& Haspelmath 2013) allows the user to draw a fine-grained map of the patternings of some 192 linguistic features and their combinations. Probabilistic techniques are increasingly used to differentiate areal signals of language contact from inherited traits using such data. Looking at an expression like "Asia and Europe" from such a modern typological perspective, one might point out, for instance, that Eurasian languages may be quite differentiated with respect to the means of grouping simple nouns $(\mathrm{N})$ and noun phrases (NP) together. Broadly speaking, there are two different strategies: some languages join NPs using an equivalent of the English conjunction "and", while they have a lexically and morphosyntactically different strategy to express the meaning "(together) with", usually by means of a "comitative" preposition unrelated to the cojunction "and". In other languages, the meaning of "Europe and Asia" would not be constructed differently from "Europe together with Asia". There are many subtypes of "and-languages", depending, for instance, on whether they place one or two, or even no conjunction at all between, behind or before the two NPs. Neeedless to say, not all such linguistic types are stable across historical time; nor are the two types in all cases fully discrete, although they tend to be with remarkable statistical preponderance. What is interesting to note, however, is that and-and with-languages have a very clear geographic distribution, which quite neatly separates "Old World" languages (belonging to the Indo-European, Uralic, Altaic, Dravidian, Semitic, and Kartvelian families and including some isolates such as Basque, Ket and Burushaski) which prefer and from a large unbroken with-area, which stretches across East and South-East Asia, insular Indonesia, Melanesia, and Polynesia. Moreover, the and/with-distinction correlates markedly with the presence of two other parameters: While and-languages are "cased" and "tensed", i.e. they obligatorily mark grammatical case on noun phrases and tense distinctions in the verb morphology, with-languages are not (Stassen 2000).

Against this background, it is easy to see how contemporary philosophers, psychoanalysts or proponents of cultural studies might be tempted to play the "linguistic relativity" game using such data on linguistic means of connecting in the languages of Asia and Europe. The Asian side of the divide would, in all likelihood, be constructed as societies interested in "togetherness", in the "belonging" to a particular social group or - worse - to a specific nation; Europe would probably emerge as the idealistic union of autonomous, "individual" societies, juxtaposed through the force of a "willed" conjunctive "you and I" agreement, rather than by virtue of a notion of togetherness conceived 
along familial bonds and role ethics. It is one purpose of this essay, then, to remind us of the long prehistory of linguistic arguments in European self-identifications, and to show how they were perceptively criticized already more than a century ago. But let us begin in the present.

At one point during the recent stroll of US President Donald Trump through the Forbidden City in Beijing on 9 November 2017, Chinese President Xi Jinping 習近平 mentioned in passing that "China has a recorded history of 3,00o years." Trump, visibly trying to engage the Communist Party General Secretary in a bit of verbal sparring, countered: "I guess the oldest culture, they say, is Egypt, at 8,00o." Xi, admitting that "Egypt is a bit more ancient" did not hesitate with his rebuttal:

But the only continuous civilization inherited onwards is China. [...] Right. We people are the original people, black hair, yellow skin, inherited onwards. We call ourselves descendants of the dragon. ${ }^{6}$

The brief exchange on the beginnings of history was quickly resolved in polite laughter of the two presidential couples and their interpreters. It seems characteristic of the global resurgence of thinly veiled nationalist sentiments and of an awareness, on the Chinese side at least, that national identity claims need an anchoring in traditions of autochthonous origins and unperturbed historical continuities - never mind the constant ruptures by foreign rulers throughout the " 3000 years of recorded history" in China or the discontinuities created by the deeply anti-traditionalist revolutions of the more recent past.

The Xi-Trump dialogue in the Forbidden City was widely broadcast on international and domestic media and Chinese audiences were quick to establish a link with a very similar "who's first" debate involving China and Egypt. It had occupied the Chinese internet just two years earlier, when Sun Weidong 孫衛東, a reputable professor of geochemistry, little known outside the academic world and now at the State Key Laboratory of Mineralogy and Metallogeny of the Chinese Academy of Sciences in Guangzhou, had caused a stir by claiming that ancient Chinese bronze technology could be scientifically shown to have a Near Eastern, ultimately Northern Egyptian origin. Sun had originally developed his theory identifying the mobile pre-dynastic Western Asian Hyksos confederation as agents of the transfer of bronze metallurgy from Egypt to the East in the I990s. At that time, he was affiliated with the Xia-Shang-Zhou Chronology Project (Xia-Shang-Zhou duandai gongcheng 夏商周斷代工程), then the largest state-funded science project of the postwar period in China. ${ }^{7}$ But wherever he turned, whether to his superiors or the general public alike, his radical diffusionist ideas fell on deaf ears. He therefore quietly continued building up more and more comprehensive isotope analyses and databases, linking the origins of Shang bronze technology in the middle of the sec-

6 See e.g. Hernández \& Zhao (2017), including a link to the CCTV video of the conversation: https://youtu.be/RpW83h_kc2E (last visited 22.02.2018).

7 The background story is nicely traced in Lewis (2016), whose article on the Sun Weidong case has been retranslated into Chinese several times, sometimes producing thousands of comments in the respective online versions. 
ond millennium BCE with a long-distance diffusion from Northern Egypt. Predictably, most recent media reactions to his bold claim in the nationalist climate of the Xi Jinping era continue to be very negative. ${ }^{8}$

The Chronology Project had been established to explore the absolute chronology in China beyond the commonly acknowledged cut-off date of 84I BCE, which marks the beginning of the gonghe 共和 interregnum, i.e. the first year which Sima Qian 司馬 遷 (ca. I45-86 BCE), the nestor of Chinese historiography, felt able to reconstruct with some confidence in the Scribe's Records (Shiji 史記). ${ }^{9}$ All available datable materials, including early bronze artefacts and their inscriptions, and all scientific methodologies, whether high-tech chemical analysis or traditional textual philology, were to be used to establish a firm date for the Zhou 周 conquest over the preceding Shang 商 dynasty. Today it is fixed at I046 BCE in most history textbooks from the People's Republic of China (PRC), even if not firmly established at all. ${ }^{10}$ The project's principle investigators, it seems, were interested in bringing about an "epistemic break" within Early Chinese historiography at the turn of the new century, a reorientation which has often been labelled as "believing in antiquity" (xingu 信古) in later references. This programmatic catchword had been introduced into the discourse on Chinese history by Li Xueqin 李 學勤, the doyen of Early China studies in the PRC in 1992. ${ }^{11}$ In what one might call a counter-iconoclastic or "iconosynthetic" movement, the duandai researchers set out to overcome the alleged excesses of the Doubting Antiquity Fraction (yigu pai 疑古派) of the Republican period. The latter had dauntlessly criticized the coherence and authenticity of many purportedly pre-imperial texts in seven thick volumes entitled Disputes on Ancient History (Gushi bian 古史辨) published between 1926 and $194 \mathrm{I}^{12}$, and - much to the dismay of their contemporary depreciators - by and large succeeded in undermining the common belief in the historicity of many founding figures of Chinese civilization.

In the Chronology Project which aimed at pushing datable Chinese history into a remoter past - a past closer to the beginnings of safely datable history in the ancient Ancient Near East and the Levant, i.e. the middle of the second millenium BCE - and at reestablishing trust in the blissful in situ continuity of Chinese civilization, there was ob-

8 For an accessible recent English summary, see Sun et al. (20I6). A recent newspaper overview summarizing mostly post-Han Egyptian long-distance influences on Chinese culture in a very neutral fashion (Yang Xue 20I2) seems unaware of Sun Weidong's theory.

9 Cf. Shiji (I0.512), Shi'er zhuhou nianbiao 十二諸侯年表 “Year Tables for the Twelve Lords".

10 The literature on this topic is vast, and some twenty competing dates for the conquest have been proposed so far. For a sober overview, see e.g. Lee, Yun Kuen (2002), and cf. the literature cited in Li, Feng (2009: 27 n. I).

11 The movement rose to prominence through Li’s eponymous collection of essays ( $\mathrm{Li}$ 1994), which has seen many reprints. Succinct statements of the foundational ideas of this "neo-con" Ancient History camp include Li Xueqin (2012) and Liu Qiyu (1995), an overview of contributions under this umbrella is offered in Wang Xuedian (2010). Two interesting Chinese critiques of the movement are Lin Yun (2007) and Zhou Shucan (2009).

12 For overviews of the "Disputes" movement, see Richter (1992) and Moloughney (20II). Its Late Imperial Chinese prehistory is sketched in Chao Fulin (1999), the considerable influence of Western and Japanese sinology on its emergence is traced in an excellent contribution by Li Xiaoqian (2013). 
viously little room for discussions about foreign influences. Much unlike their modern duandai detractors at the end of the twentieth century, the yigu skeptics of the 1920s-30s were surprisingly open in allowing the possibility of foreign elements in Early Chinese culture. Already in the first volume of the series, the Gushi bian figurehead and intellectual front man of the "May Fourth" reform movement Hu Shi 胡適 (I89I-I962) went so far as to claim a common origin for the two central early Chinese theonyms $d i$ 帝 and tian 天 with Indo-European names for 'God' (such as Sanskrit deva-, Latin deus, and Greek Zeus ${ }^{13}$ ) (Hu Shi 1923), only to be outmaneuvered by the famous Chinese linguist and vernacular poet Liu Bannong 劉半農 (I89I-I934; style Fu 復) a few years later in volume II, who traced the origins of the Shang and Zhou deities to Babylonian ancestors (Liu Fu 1926). Incidentally, another, theory popular since at least the middle of the nineteenth century in the West (cf. Schott I860: 6I8; Watters I889: 356-357, 362), had used the phonetic similarity of tian with the name of the supreme Eurasian Sky God attested as Proto-Turkic *tenri / *änri and alleged Tunguso-Mongolic cognates ${ }^{14}$ to argue for an "Altaic" background of tian 天 and, a fortiori, a steppe origin of the Zhou founders of Classical China. The once popular Altaic origin theory of the central Chinese deity name has been rendered unlikely by Edwin Pulleyblank's discovery (Pulleyblank 1962: II7-II9), that the word tian belongs to a phonetic series, which is today reconstructed with an Old Chinese lateral, rather than with a dental initial (Old Chinese * ${ }_{0} \mathrm{in}^{15}$ ). If related at all, either the Chinese or the Turkic word would therefore have to be a rather late (Han?) borrowing, almost a millennium too late to postulate a connection with the God-on-high of the Zhou people. Moreover, Ralph-Stefan Georg has carefully argued that the "Altaic" word is itself a loanword from Yeniseian, the putative language of the Xiongnu 匈奴 elite, in whose language *tingVr- means "high" and instantiates a widespread areal trend to derive theonyms from roots having "elevated" semantics (Georg 200I). The construction of civilizational precedence through linguistic comparisons of key terms, such as the central theonyms just mentioned, is a trope with a long prehistory in European accounts of China. While it seems to be relatively absent in medieval sources (Reichert 1992; Münkler 2000) ${ }^{16}$, it becomes a recurrent argumentative pattern from the beginnings of the seventeenth century and onwards in Europe.

13 I.e. cognates of the Indo-Eropean root *dieu- "heaven" and its thematic derivation *deiuo- "the heavenly one" (Beekes \& van Beek 20I0: 498-499). Given the surface resemblance of Greek $\theta \varepsilon \dot{s} \varsigma$ "god, goddess" (from Indo-European * $\mathrm{d}^{\mathrm{h}}(\mathrm{e}) \mathrm{h}_{1} \mathrm{~s}$ - "god", (Beekes \& van Beek 20I0: 540), cognate with Latin fêriae "festive days") with Latin deus, a connection encountered well into the twentieth century in popular sources, it is remarkable that Hu Shi steered clear from that mistake. For the most recent recycling of this idea, see Zhou Jixu (2005).

14 For overviews of the forms and other etymological theories, see e.g. Doerfer (1965: 577-585/\#944), Rybatzki (2006: 40I-4IO, s.v. tenggeri), Dybo (2007: 82-84, s.v. “небо: 撐黎”).

15 Old Chinese "(OC) *reconstructions" and Middle Chinese "(MC) *transcriptions" are cited according to the system of Baxter \& Sagart (20I4).

16 For a historical panorama of the reverse perspective of Chinese "occidentalism", see Wang Mingming (2014). 


\section{Sino-Egyptian}

Few scholars battling over the question of the origins of Chinese civilization during the Republican period and even less today seem to have been aware of their predecessors, who had already probed into the "Egypt vs. China" topos rehearsed by Trump and $\mathrm{Xi}$ during a period when the Jesuit missionary accounts shook hitherto unquestioned Biblical chronologies and narratives in Europe. The Jesuit scholar Athanasius Kircher (1602-1680), the "last man who knew everything", ${ }^{17}$ had pioneered Sino-Egyptian comparisons in his Oedipus aegyptiacus (Kircher 1652-1654), China illustrata (Kircher 1667), Turris Babel (Kircher I679) and other works. ${ }^{18}$ Always eager to look beyond Biblical and Medieval origin stories into the Thoth/Hermes Trismegistus-narratives embedded in the Corpus Hermeticum and other neo-Platonist and gnostic writings of Late Antiquity, many early Renaissance thinkers were inclined to accept revelatory mysteries from Pharaonic Egypt (Saussy 20II: 49). When the new information about China received through the Jesuit missionaries had to be fitted into such narratives, Kircher claimed that not only were there substantial religious, ritual and ceremonial similarities between Ancient Egyptian and Chinese institutions but, more importantly, the Chinese writing system and hence, Chinese civilization writ large, could be shown to be derivative from Egypt. ${ }^{19}$ In a trans-Eurasian long-distance diffusion movement, Cham, the third son of Noah, would have reached the borderlands of China in Mongolia via Persia and Bactria in remote antiquity and brought writing and other elements of civilization to China. Through such narratives, China as a region of "Gog and Magog", in "ultima thule", or on other fringes of the inhabitable world, became slowly incorporated into varying versions of the bibical Tower of Babel story and aligned with other "pagan" languages which had to be accomodated in lists of the 72 post-dispersal tongues. ${ }^{20}$

Other, less cosmopolitan German authors of the period, like the baroque poet and playwright Daniel Casper von Lohenstein (1635-I683) were prepared to demote Egypt as the first civilization, at least in their somewhat kitschy allegorical poetry, in which the Chinese porcelain pagodas could win out over Egyptian pyramids full of "corpses, smell and worms." ${ }^{21}$ As Janine Hartman has shown, the Sino-Egyptian debate has to be read against the canvas of a deep intellectual crisis growing out of the Renaissance and the religious wars accompanying reformation and counter-reformation - Kircher had studied Coptic while hiding from the ravagings of the Thirty Year War in Avignon

17 To borrow the subtitle from Paula Findlen's volume (Findlen 2003).

18 Good summaries of Kircher's theories about Chinese include Szczesniak (1949-55; 1952) and Luca (2OI2).

19 See on the writing system aspect especially Allen (1960), Saussy (200I: 43, 49-50), Rusk (2007: 95-106) and Klock-Fontanille (2010).

20 For extensive treatments of the Ancient Near Eastern, Biblical and Medieval European language dispersal narratives see Borst (1957-1963) and Uehlinger (1990, 2014). Chinese first appears in the 72 language lists in the ninth century, but its position with Jewish, Oriental Christian, Muslim and early Medieval authors before Marco Polo (I254-I324) remains quite volatile, cf. Borst (I995, I: 193, 276, 335-343, 695, 772, 848).

21 See e.g. the epigram "Egypten, bücke dich und deine spitz'gen Thürme [...]" ("Bend down, Egypt, with your tapered towers"), cited in von Tscharner (1939: 44). 
- which resulted in the need for Early Modern Europe to "incorporate exotic societies into its own history, or insist on their alienness to undermine that history" (Hartman I998: II6). Many other European scholars in the seventeenth and eighteenth century followed suit, especially in France and England, garnering more or less fanciful evidence for the Egyptian origin theory, often demonstrably in attempts to dodge the threat which the supposed antediluvian antiquity of Chinese chronologies, communicated by the Jesuit missionaries, seemed to pose for European Christianity (Hartman I998: I09). ${ }^{22}$ With barely restrained sarcasm and copious attention to the primary sources, Henri Cordier (1849-1925), one of the towering figures of French sinology at the turn of the nineteenth and twentieth centuries, reviewed the quick succession of scholars engaged in the "fantaisie sinico-égyptienne" in the introductory chapter of the first volume of his monumental Histoire générale de la Chine (Cordier 1920: I-39). ${ }^{23}$ Cordier identified Pierre-Daniel Huet (I630-I72I), the Bishop of Soissons and Avranches, Jean-Jacques Dortous de Mairan (I678-I77I), a renowned astronomer, linguist and chronobiologist, William Warburton (I698-I779), the Bishop of Gloucester, and John Turberville Needham (I7I3-I78I), a British priest, botanist and natural philosopher, as ardent supporters of the idea. It probably received its most forceful formulation through Joseph de Guignes (I727-I800), secrétaire-interprète at the French Royal Academy and later professor of Syriac at the Collège de France, whose Mémoire dans lequel on prouve que les Chinois sont une colonie Egyptienne presented to the French Academy on I4 November I758 and many similar later writings were heatedly debated in European scholarly circles, only diffidently at the time.

Predictably, the Egyptian origins idea also attracted a considerable amount of enmity from quite a few prominent commentators. ${ }^{24}$ But the most vocal critic was certainly Voltaire (I694-1798) whose fragment "Si les Égyptiens ont peuplé la Chine, et si les Chinois ont mangé des hommes" merits quoting: ${ }^{25}$

It has occurred to us, for instance, that the Chinese are no more descendants from an Egyptian colony than from a colony of Lower Brittany. Those who had claimed that the Egyptians had colonized China have exercised their spirits and that of others. We have

22 I am skipping the considerable role of Jesuit Figurism in this development, which has been amply described elsewhere, see e.g. Rowbotham (1956), von Collani (198I; 1985), Lundbæk (199I) and Kern (1998: 270-7I). For a complementary view on how Islamic and Jewish authors dealt with the same chronological disquiet, see Leslie (1984).

23 Other good summaries of the Sino-Egyptian theme include Szczesniak (1952), Hartman (1998) the latter, like Zhou Shucan (2016) largely dependent on Cordier's narrative - and Leung (2002: I2O-I28).

24 These include Nicolas Frérét (I688-1749), a scholar of antiquity and the history of religions, and one of the first serious students of Chinese in Europe; Michel-Ange-André Leroux Deshauterayes (1724-1795), orientalist and one of the first Manchurists in Europe, like de Guignes a student of Étienne Fourmant (1683-1745), the nestor of Chinese grammar studies in Europe, who was his uncle; the Dutch rationalist philosopher and ethnographer of Mesoamerica and Siberia Cornelius Franciscus de Pauw (1739-I799), who spent a considerable part of his adult life as a diplomat at the court of Frederick the Great of Prussia.

25 In the following, all translations, unless otherwise marked, are my own. 
applauded their erudition and efforts; but neither the figure of the Chinese, nor their manners, language, writing or customs have anything of ancient Egypt. They never knew circumcision; none of the Egyptian deities reached them; they still ignored the mysteries of Isis. ${ }^{26}$

Voltaire's interest in promoting the image of an age-old, atheist, highly cultivated and rationalist China, whose chronologies have been corroborated "par le témoignage unanime de nos voyageurs de différentes sectes, jacobins, jésuites, luthériens, calvinistes, anglicans; tous intéressés à se contredire", is well known. ${ }^{27}$ In his rejection of Biblical chronology and of simple European appropriations of oriental histories he is a prototypical Enlightenment philosopher before the negative turn of the European image of China. $^{28}$

Later excrescences of Kircher's Sino-Egyptian idea, which survived the French Revolution, were less interested in chronological implications for the origins of civilization and religion, than in the genealogy of writing systems and languages, meandering back and forth between universalist claims and diffusionist contact scenarios, - a conflict which eventually came to characterize much of twentieth century historical linguistics as well. Thus, Jean Pierre Guillaume Pauthier (I8OI-I873), one of the most important mediators of Daoist and Confucian classics in Europe (Pauthier 1831; 1837b; I84I; I842a), author of a history of China which was retranslated into several European languages (Pauthier I837a), and editor cum translator of an anthology of hymnic poetry in Sanskrit, Persian, Egyptian and Assyrian (Pauthier 1872), produced a learned treatise entitled Sinico-Aegyptiaca (Pauthier I842b). In it, the "six ways of writing" (liu shu 六書), the structural principles of the Chinese writing system laid out in the Eastern Han dynasty, ${ }^{29}$ were compared with Egyptian hieroglyphs. Concluding on a universalist note, he wrote that the resemblance between the two systems "[...] is due to the general laws of the human spirit, which manifests itself in the same manner on the banks of the Nile as on those of the Yellow River" (Pauthier I842b: IO6). ${ }^{30}$ Quite untypical of the genealogical discussions of the preceding decades in France, he was preceded in this perception by Jean-François Champollion (I790-I832), who had already clarified

26 "Il nous a paru, par exemple, que les Chinois ne descendent pas plus d'une colonie d'Égypte que d'une colonie de Basse Bretagne. Ceux qui ont prétendu que les Égyptiens avaient peuplé la Chine ont exercé leur esprit et celui des autres. Nous avons applaudi à leur érudition et à leurs efforts; mais ni la figure des Chinois, ni leurs mœurs, ni leur langage, ni leur écriture, ni leurs usages, n'ont rien de l'antique Égypte. Ils ne connurent jamais la circoncision: aucune des divinités égyptiennes ne parvint jusqu'à eux; ils ignorèrent toujours les mystères d'Isis". Voltaire, Euvres complètes, Mélanges VIII, Paris: Garnier, 1879: 234-235, cited from Cordier (1920: 20).

27 Introduction to Essai sur les Mours, apud Cordier (1920: 47).

28 Well-documented in Guy (I963), Terol Rojo (20I5: 352-378) and esp. Lee (2003: I4I-334, chap. II: "Konfuzianische Herrschaft als Symbol der Reaktion: Interpretationen zwischen 1770-I840").

29 A good introduction to the highly disputed topic in English is Boltz (2017). Chinese works using liush $u$ theories to discuss Eygptian hieroglyphs are surveyed in Wang Haili (2015); its application to Sumerian cuneiform is discussed in Gong Yushu (1998).

30 "[...] est dû au lois générales de l'esprit humaine, qui se manifestent également sur les bords du Nil comme sur ceux du flauve Jaune". 
in his pathbreaking Précis (Champollion I824/I828) presenting the full decipherment of Hieroglyphic Egyptian, that "[...] since ancient times, just like today, the Chinese script and the Egyptian script only shared a few general principles and that they differ greatly in several important respects" (Champollion I828: 345). ${ }^{31}$ Under the impression of such European discussions about early Sino-Egyptian relationships, Late Qing dynasty (I644-I9I2) Chinese travellers to Europe began to show some interest in comparisons between the two writing systems during visits to the major Egyptian collections in European museums. One of the earliest Chinese references to Egyptian writing is found in the Cheng cha biji 乘槎筆記 (Jottings on a Raft Ride) of the Manchu bannerman Binchun 斌春 (I803-?) who travelled through Europe as a Qing government official in the I86os. ${ }^{32}$ In his diary he states that the graphs on the Egyptian pyramids are "reminiscent of old bronze inscriptions on bells and tripods” (ru gu zhongding wen 如古鐘鼎文) in an entry for $1866 .{ }^{33}$ His fellow traveller, the tongwenguan 同文館 English interpreter Zhang Deyi 張德㝝系 (I847-19I8) notes in his Hanghai shuqi 航海述奇 (Description of Mirabilia Travelling at Sea) that the Egyptian "characters were like bird seal script" (zi ru niaozhuan 字如鳥管), referring to a highly aestheticized style of Warring States bronze inscriptions which embellishes characters with bird-elements. ${ }^{34}$ Wang Tao 王 韜, in his Manyou suilu 漫遊随錄 (Selected jottings on carefree roamings) of $1898,{ }^{35}$ felt reminded of “tadpole writing” (kedou wen 蝌蚪文), i.e. of the pre-unification seal script type associated with the rediscovery of books in the walls of Confucius house which had survived the Qin "bibliocaust" of 213 BCE. It was probably he who initiated discussions of hieroglyphs with reference to the traditional Chinese "six scripts" terminology. Since the Lundun yu Bali riji 倫敦與巴黎日記 (London and Paris Diaries) of I89I by the first Qing ambassador to the United Kingdom Guo Songtao 郭高濤 (I8I8-I89I), who procured hand copies and photographs of hieroglyphic inscriptions during a stay in Egypt in 1876 later circulated in China, Chinese scholars also began to discuss the diachronic sequence of the "six types of writing" in both, the Egyptian and the Chinese systems, along with broader questions of writing origins. Guo also introduced Champollion's decipherment of the Rosetta stone to a Chinese audience and the comparison became a quite frequent topic of newspaper articles and quotidian exoticizing poetry at the end of the nineteenth century.

31 "[...] dès les temps anciens comme aujourd'hui, l'écriture chinoise et l'écriture égyptienne n'ont eu de commun que quelques principes généraux et qu'elles diffèrent fort essentiellement sur plusieurs points important." An interesting discussion of how Champollion's parenthetical use of one of the three sign functions (established by him for Egyptian) for Chinese writing as a whole may be at the root of the European "ideography" topos is offered in Saussy (200I: 45-46).

32 I am relying heavily on the excellent sketches of early Chinese engagements with Egyptian writing presented in Ji Changming \& Yang Junming (1995) and Wang Haili (2015) in this section. See on Binchun's travels in Europe also Wang Mingming (20I4: I-7).

33 Cited in Ji Changming \& Yang Junming (1995: 84).

34 Cited in Ji Changming \& Yang Junming (1995: 84), Wang Haili (2015: 280). Useful studies of this peculiar writing system include Rong Geng (1964), Ma Chengyuan (1983), Cao Jinyan (1999) and Yan Zhibin (200I).

35 For a good introduction to the work and its background, see Tsui Wai (2009). 
The first sophisticated comparison of the two writing systems that I am aware of, which is paleographically informed on the Egyptian and the Chinese side, only appeared half a century later, when Won Kenn (a.k.a. Won Kemm, Huang Juansheng 黄 涓生, Huang Zunsheng 黄尊生 and Huang Juansheng 黃鵑聲, I894-1990) ${ }^{36}$ presented a slim comparative treatise based on his Université de Lyon dissertation of 1925 (Won Kenn 1926). In it he used Chinese bronze inscriptions, finding typological parallels to some but not all structural principles of Egyptian writing. ${ }^{37}$ Like Pauthier he stressed the genealogical independence of the two écritures-soeurs (Won 1926: 89). He held that the use of acrophony in Eygptian hieroglyphic writing, which - arguably - brought about the later "alphabetical revolution" (e.g. Goldwasser 20I0), was inhibited on the Chinese side by the greater importance of vowels in the underlying phonology of Chinese (Wong 1926: 84-85). This contention is still a topic hotly debated in grammatological circles today, as is the idea of a comparable role of Egyptian determinatives or "classifiers" and Chinese "radicals" (Won 1926: 79-83; cf. Chen Yongsheng 20I6). A differentiated picture like Won's could obviously not result in a neat diachrony of precedence. While he considered Egyptian hieroglyphs "much more developed" on account of the presence of acrophony and judged their aesthetic value to be higher, he also thought of them as too complex in acquisition, excessive in their combinatorial principles for semantic, classifying-determinative and phonetic components, and, above all, too overburdened by the need for artistic faithfulness vis-à-vis the depicted object. Chinese on the other hand, seemed less advanced to him, since it had not yet "developed" precise depictiveness; but it was also less complex and easier to acquire as a system (Won 1926: 88-89). Roughly at the same time, but working independently at the other end of the Eurasia, the Japanese physician Itatsu Shichisaburō 板律七三郎 (self transcription: Itazu Hichisaburō, I866?) also compiled a massive compendium of Sino-Egyptian pictographic comparisons (Itatsu 1933, I935), in an attempt to uncover the original "picturesque delineation" which had given rise to the manifold similarities (Itatsu 1933, English appendix: 2) between the systems.

Most authors of this early period of Sino-Egyptian encounters tended towards a universalist stance, refuting claims to an Egyptian origin of Chinese writing and vice versa. Already Wang Tao (1828-1897), James Legge's (I840-1873) indefatigable translation amanuensis, passionate traveller, and probably the most important cultural mediator between China and the West in the nineteenth century, had stated that "in origin, there was no difference between the Chinese and the foreign [systems]" (yuan wu fen zhong wai 原無分中外). ${ }^{38}$ And one of the most eloquent critics of theories of the Western origins of Chinese civilization He Bingsong 何炳松 (I890-1946), systematically sorting

36 Won is otherwise mostly remembered for his involvement in the Chinese anarchist and Esperanto movements. For the close relationship between the two movements, see Müller-Saini \& Benton (2006) and Di Sebastiano (2013/I4: I5-23). A short biography of Huang is found in Li Yisan (2008), a brief autobiography in Huang Zunsheng (2008).

37 Won also published a slightly rewritten Chinese version of the comparison using liu shu terminology (Huang Zunsheng 1942).

38 Man you sui lu, p. 80, cited from Ji \& Yang (1995: 84). 
and tabulating nine foreign origin theories from the fifty-seventh year of the kangxi 康 熙 reign (=I7I8) to the ninth year of the tongzhi 同治 reign (=I870) presented by Western authors, simply echoes Pauthier, when he ascribes the commonalities between the two systems to "shared tendencies in the efforts of the spirit of humankind" (renlei jingshen nuli zhi tongxiang 人類精神努力之通向). ${ }^{39}$

\section{Sino-Babylonian}

While the works of Pauthier, Won and Itatsu remained largely unknown outside specialist circles, it was a somewhat different kind of Near-Eastern-Chinese connection which occupied diffusionist minds during the last quarter of the nineteenth century in Europe. Already Athanasius Kircher had been wavering between the idea of a direct influence of Egypt on China or one mediated by the West Semitic speaking Chaldeans, a people which he dated much earlier than what is now assumed to be their first historical attestation in Southestern Mesopotamia at the beginning of the first millennium BCE. But the creation of an alternative Sino-Chaldean origin narrative to Babylonia and, ultimately of a whole "Pan-Sumerian" movement in Japan and China, is largely due to Albert Étienne Jean-Baptiste Terrien de Lacouperie (I844-1894). Little is known about his Hong Kong youth and training in business, after his family of silk merchants had relocated there from the Normandie, and even less about how he established himself in London, first as a fellow of the Royal Asiatic Society in I879, then as a professor of Comparative Philology at University College in I884 (Carlyle I898).

Since the early I880s he had developed in a number of articles first published in his journal The Babylonian and Oriental Records then, more concisely, in his book Western Origins of the Early Chinese Civilization from 2300 B.C. to 200 A.D. (Terrien de Lacouperie I894), a theory about the migration of the Bak sing (i.e. baixing 百姓, Old Chinese ${ }^{*} \mathrm{p}^{\uparrow}$ rak-sens) tribe from Elam to China in the twenty-third century B.C. and the founding of Chinese civilization under Sargon I of Akkad (trad. reg. 2334-2284 BCE). It is very likely that the Sino-Babylonian narrative of Terrien de Lacouperie was directly inspired by two other early Western residents of China, Joseph Edkins (I823-1905) and Thomas Kingsmill (1837-1910), operating outside the mainstream of European academic sinology, who had proposed "Sino-Aryan" a decade earlier. Both theories continued to overlap until well into the early twentieth century. Edkins and Kingsmill both shared a conviction that the Chinese and Indo-European language families were genealogically related, even if for somewhat different ends. While Edkins still dreamt of an "adamitic" reconciliation of Chinese, Indo-European and Semitic in the light of pre-Babelian monogenetic origins and Biblical chronologies, Kingsmill's motives were clearly more mundane. He sought to establish Aryan cultural and racial supremacy by "uncovering" the indebtedness of the earliest Chinese classics to Indo-European vocabulary, customs and institutions (Girardot 2002: 153-I6I; Penny 2007; Behr 2015).

The extraordinary story of Terrien de Lacouperie's hyperdiffusionist idea, based on shaky phonological equations, comparisons between cuneiform signs and Chinese small

39 He Bingsong (1929), cited from Ji \& Yang (1995: 86-87). 
seal script, and hundreds of Mesopotamian-Chinese cultural equations, has been told in lavish detail elsewhere. ${ }^{40}$ It is sufficient to remind us here that his theory, "doué de plus d'imagination que de science" (Cordier 1920: 28), enjoyed enormous popularity among leading anti-Manchu intellectuals in China, such as Zhang Binglin 章炳麟 (1869-1963), Liang Qichao 梁啟超 (I873-I929) or Liu Shipei 劉師培 (I884-I919) for a few years (Li Fan 2005). It was so influential that the national anthem under the Yuan Shikai 袁世 凱 (I859-I916) Republic of I9I5 “Chinese heroes establishing themselves in the cosmos" (Zhonghua xiong li yuzhou jian 中華雄立宇宙間) featured a line referring to the "pedigree of the Huá coming from the peaks of the Kunlun mountains" (Hua zhou lai cong Kunlun ling 華胄來從芘崙真). Terrien de Lacouperie's book and its sequels were even more popular in Japan. And in England they engendered further long-forgotten SinoSumerian works, such as the catalogue of Chinese and Sumerian character lookalikes published by C. J. Ball, the later Professor of Assyriology at Oxford, in I913. One cannot help but notice that all these Late Imperial and Republican period Sino-Xenic origin theories are but modifications of a similar argumentative structure. Their life-cycle, it seems, was usually negatively proportional to the room their authors were prepared to leave for early linguistic contacts and historical entanglements, beyond a straightforward reduction to geopolitical precedence and authority claims. The European conflation of Chaldean cuneiform, Egyptian hieroglyphs and Chinese characters followed the positivist and increasingly historicist trends of the late nineteenth century in constructing intricate Transeurasian genealogies of precedence and diffusion. While twentieth century authors often continued to lump together non-alphabetic writing systems in a non-discriminatory fashion, their interest had shifted away from historical descent to their symbolic and semiotic functions.

\section{Psychoanalytic Associations of Chinese Writing}

Jacques Lacan had studied Chinese from 1942 to 1945 , during the Nazi occupation of France, under the great Franco-Swiss sinologist Paul Demiéville (I894-1979) ${ }^{41}$ and obtained a degree from the École nationale des langues orientales vivantes in Paris (Flecher n.d.: 4; Serrano 1997: 93). In the middle of a very turbulent love and family life and facing demanding work responsibilities at the hospital, already twice as old as some of his fellow students, he had carved out time to attend classes twice weekly, determined to master the Classical language and its writing system (cf. Roudinesco I997: I2I-200). Unsurprisingly, he went on to use Chinese topoi and citations throughout his whole academic career after the end of the Nazi occupation, when he started to publish again in $1946 .{ }^{42}$ Often playfully irritating the post-war audiences of the famous séminaires with wild dissections of Chinese characters or risqué interpretations of phrases from

40 See especially Yang Sixin (1999; 2003), Girardot (2002: 384-392), Kaske (2008: 34I-347), Matten (2009: 73-82), Li Fan (2008a, b), van Binsbergen (2009/10), Sun Jiang (2010), Yen (2014: 9-15), and Smith (2017).

41 On Demiéville, see the obituaries in Gernet (I979), Durt (I980) and Hervouet (I98I).

42 He had stopped all publication activities under the occupation (Roudinesco 1994: I2I). Lacan's China related quotations and a wide range of essays about his involvement with China are now 
the Confucian and Daoist classics, usually just vaguely associated to the theme he happened to lecture on, he played a central role in the surprisingly frequent engagement of the French psychoanalytic community with Chinese topics, ${ }^{43}$ even before the intensive affair the Tel Quel group had with Maoism. ${ }^{44}$ Lacan had been offered membership of the delegation to the People's Republic headed by Philippe Sollers at the height of the $p i$ Lin pi Kong 批林批孔 (Criticize Lin [Biao], criticize Kon[fucuius]) campaign between II April and 4 May 1974. But he declined on the grounds that "he hadn't been able to learn enough Chinese to have a conversation with the people" and was replaced during the "pilgrimage" by Roland Barthes (Paquet 20I6: 363 ).

A typical example of Lacan's invocation of Chinese themes includes his use of the “line symbols” (gua 卦) of the Classic of Changes (Yijing 易經), that is, the solid and broken lines which are combined into tri- and hexagrams in traditional milfoil divination, ${ }^{45}$ as a metaphor for the language of the unconscious encountered in dreams. Intentionally punning on the French interrogative quoi?, the gua were claimed to gesture at "a thing in its most general, undefined sense" (Serrano 1997: IOI-2). The discourse of non-alphabetic writing as a practice that transgresses individual languages and that is capable of revealing the nature of prelapsarian mysteries had first developed in sixteenth century Neo-Platonism (Curran 1998-99; Hamann 2008: I4-16) and found a happy playground in the Jesuit lettres édifiantes about China (Luca 2016: 19-72). As Rainier Lanselle has pointed out, Lacan's frequent invocation of characters - whether ultimately referring to personality traits or stroke configurations - was directly inspired by Freud, who had already flirted with the "semantophoric" nature of hieroglyphic writing in his Traumdeutung (Freud 1900: 319; cf. Birman 2007: 204; Lanselle 20I0a: 314-5). Lacan himself refers to this connection, in uncharacteristic transparency, in one passage from 26 September 1949, swiftly extending Freud's Egyptian metaphor to Chinese "phonosemantic” characters (xingshengzi 形聲字):

So let's pick up the work by Freud at the Traumdeutung in order to remember from there that the dream has the structure of a sentence, or rather, sticking to his exact wording, of a rebus, that is to say of a script, such that the dream of the child would represent the primordial ideography, and that it reproduces the concomitant phonetic and symbolic use of the signifying elements in the adult that can be found in the hieroglyphs of ancient

conveniently assembled at the website of the Strasbourg psychiatrist Guy Flecher, "Lacan et le monde chinois" (http://www.lacanchine.com/Accueil.html, last visited 22.12.2017).

43 See on this topic Porret (2008), to be read in conjunction with Lanselle (20IOa, b), and Lu Yachuan (20I0). The online bibliography "Psychanalyse et Monde chinois" of Flecher (http://www. lacanchine.com/Biblio_Psy.html, last visited 2I.I2.20I7) counts some 40 titles beyond the many articles and essays gathered on his website.

44 For overviews, see Bourseiller (1996), Hourmant (1997), Hayot (1999: I46-243), Wolin (2012); for the somewhat different German and Swiss counterparts, see also the contributions to Gehrig, Mittler \& Wemheuer (2008).

45 As we have known since I980, however, it is mistaken to think of these symbols as milfoil stalks, or as a "trace sur le sable" (as per Lacan 1956: I02, alluding to the Yijing arrative of writing origins). They first appear engraved into Early Western Zhou oracle bones and cast into bronze inscriptions, cf. Zhang Zhenglang (I980) = Shaughnessy transl. (I980-8I). 
Egypt just as well as in the characters of which China preserves this [double] usage (Lacan I996: 267$) \cdot{ }^{46}$

Here, the rebus nature embedded into the logographic writing systems of Chinese and Egyptian is seen as functioning along the lines of jokes, slips of the tongue, assonances, puns etc. as a privileged access route to the unconscious (Freud 1900: 507-9), which Lacan saw, after his famous "retour à Freud" of 1953 , as structured like a language. ${ }^{47}$ More specifically, it is the role of determinatives ${ }^{48}$ - those elements in the construction of a character which differentiate otherwise homo(io)phonic phonophores by assigning them to a prototypical semantic range - which are treated as adult clues to the "pure" signification of the symbols occurring in a child's dream. Like the reader of a Chinese character pronounced niè differentiates between the homophones niè 聶 (Old Chinese

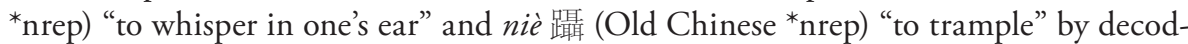
ing the semantic determinative $z \dot{u}$ 足 “foot” in the second instance, the analyst will have to decode those symbols in a dream which are part of the language of the unconscious. Looking more closely, Freud was somewhat more careful than Lacan, when he limits the usefulness of the "determinative" metaphor elsewhere in his chapter on the "The dream's means of expression" (Die Darstellungsmittel des Traumes). If the conflation of properties of existing persons or situations into one Mischperson fails, he elaborates, and the contents of what they signify is spread across different persons appearing in a dream, then one person - often the less prominent one - behaves towards the other person like a determinative "[...] in hieroglyphic writing, which is not intended to be pronounced, but merely as an elucidation of another sign" (Freud 1900: 315). It is not the signs' "ideographic" nature or rebus function per se, which offers a quasi-magical access to latent thoughts or the unconscious, but only their way of "diacritic" signification, which is compared to the subdued functioning of certain symbol classes within dreams. Freud does talk about Chinese writing in another passage of the Traumarbeit as well, but there it only serves as a very general comparison for the precariousness of dream analysis arising from a similar degree of context dependence and polysemy:

The uncertainties which still adhere to our function as dream-interpreters are due partly to our imperfect knowledge (which, however, can be progressively increased) and partly to certain peculiarities of the dream-symbols themselves. These often possess many and

46 “Qu'on reprenne donc l'œuvre de Freud à la Traumdeutung pour s'y rappeler que le rêve a la structure d'une phrase, ou plutôt, à nous en tenir à sa lettre, d'un rébus, c'est-à-dire d'une écriture, donc le rêve de l'enfant représenterait l'idéographie primordiale, et qui chez l'adulte reproduit l'emploi phonétique et symbolique à la fois des éléments signifiants, que l'on retrouve aussi bien dans les hiéroglyphes de l'ancienne Égypte que dans les caractères dont la Chine conserve l'usage".

47 In a typical "telquelian" extension, Julia Kristeva would later go so far as to ascribe that privileged access to Chinese poetry as a whole (cf. Hayot I999: 170-I82).

48 This is the term used in Eygptology and Sumerology for what is usually referred to as "significs", "semantics" or "semantophores" in the sinological tradition, or as "keys" (clefs) "class heads" (bushou 部首) or, indeed "radicals" with respect to their ordering function in lexicography. On the historical misnomer "radical" and the associated idea that these elements represent the semantic roots of a lexeme, see Behr \& Söderblom-Saarela (forthcoming). 
varied meanings, so that, as in Chinese script, only the context can furnish the correct meaning. This multiple significance of the symbol is allied to the dream's faculty of admitting over-interpretations, of representing, in the same content, various wish-impulses and thought-formations, often of a widely divergent character (Freud 1913: 168; A.A. Brill transl.). ${ }^{49}$

In a similar "free association" mode, Lacan argues that the rebus mode of psychoanalytic access is comparable to the reductions of a wide range of verb forms to the monosyllable $d a$ by the ancient Indian creator god Prajāpati in a dialogue of the Bridadäranyaka Upanisad (Lacan 1966: 322), which have to be unravelled by the devas, humans and asuras in the same way as the analyst translates the language of the patient (Serrano 1997: I03-4), at the same time linking the cosmos and the human psyche through one maximally reduced, yet powerful sound. ${ }^{50}$

The vast, but never boundless or unstructured polysemy arising from the "monosyllabic nature of Chinese", offers an even better comparison beyond the confines of the writing system, for it frees the language from the fetters of Indo-European roots. Lacan writes (I6 March 1960):

The development of roots and radicals in inflecting languages is something that poses special problems which are far removed from being applicable to the universality of languages. It would be very difficult to develop for what characterizes Chinese where all signifying elements are monosyllabic. ${ }^{51}$

\section{Monosyllabism}

In Lacan's juxtaposition of inflection and monosyllabism, we can easily discern another distant echo from a long-standing European tradition beyond the symbolic harnessing of non-alphabetic writing which associates the "monosyllabicity" of Chinese with a pristine, "natural" state of language development. In the seventeenth century this idea

49 "Die Unsicherheiten, die unserer Tätigkeit als Deuter des Traumes noch anhaften, rühren zum Teil von unserer unvollkommenen Erkenntnis her, die durch weitere Vertiefung fortschreitend gehoben werden kann, zum anderen Teil hängen sie gerade von gewissen Eigenschaften der Traumsymbole ab. Dieselben sind oft viel- und mehrdeutig, so daß, wie in der chinesischen Schrift, erst der Zusammenhang die jedesmal richtige Auffassung ermöglicht. Mit dieser Vieldeutigkeit der Symbole verbindet sich dann die Eignung des Traumes, Überdeutungen zuzulassen, in einem Inhalt verschiedene, oft ihrer Natur nach sehr abweichende Gedankenbildungen und Wunschregungen darzustellen" (Freud I900: 348).

50 It is undoubtedly texts like this which provoked the Habermasian Klaus Laerman to talk about the "rasende Gefasel der Gegenaufklärung" (the ranting drivel of Counter Enlightenment) (Laerman 1985) and "Lacancan and Derridada" (Laerman 1986), when French poststructuralism was all too readily embraced by the disenchanted post-socialist German left during I980s; for the historical background, see Felsch (2015: 198-235).

51 "La mise en valeur des racines et des radicaux dans les langues flexionnelles est quelque chose qui pose des problèmes particuliers qui sont loin d'être applicables à l'universalité des langues. Ce serait bien difficile à mettre en valeur pour ce qui est par exemple du chinois où tous les éléments signifiants sont monosyllabiques" (Lacan 1986: 36 ). 
was still conceptualized in phylogenetic rather than psychoanalytic dimensions. Already the Early Modern polymath John Webb (I6II-I672), architect, Stonehenge scholar, and author of the earliest work in English devoted to the Chinese language (An Historical Essay Endeavoring a Probability that the Language of the Empire of China is the Primitive Language, I669), had stressed that:

[...] the Chinois are never put to that irkesome vexation of searching out a Radix for the derivation of their words, as generally all other Nations are; but the Radix is the word, and the word the Radix, and the syllable the same also [...] they are not troubled with variety of Declensions, Conjugations, Numbers, Genders, Moods, Tenses and the like Grammatical niceties, but are absolutely free from all such perplexing accidents having no other Rules in use, than what the light of Nature hath dictated unto them; whereby their Language is plain, easie and simple, as a NATURAL speech ought to be (Webb i669: 208-9). ${ }^{52}$

And in a kind of phylo-ontogenetic shortcut, which should have a long afterlife in European sinology and philosophy, Webb also had linked this monosyllabic state of affairs in Chinese with the childlike state of its linguistic development: ${ }^{53}$

The Language of China as hath been shewed also consisteth all of Monosyllables, \& in our Infancy the first Notions of speech we have are all Monosyllables; as Ta, for Father; $M a$, for Mother; $\mathrm{Pa}$, for Brother; the like happening in all other terms, until by hearing and observing what others in our confused Language say, we alter accordingly, adding now and then a letter or syllable by degrees; whereby in the end we are brought to plain words. For, it is not by natural instinct, but by imitation, and as we are instructed that we arrive at speech [...] (Webb i669: 196-7).

Monosyllabicity turned out to become a surprisingly persistent trope in European writings about China, which has its ultimate roots in the quasi-isolating typology of Chinese at the time of its first description by the Jesuit missionary Michele Ruggieri (I543-I607) and his successors. ${ }^{54}$ Already in Gottlieb Spitzel's (I639-169I) De re litterarie Sinensium commentaris ( 1660 ), one of the first European treatises that includes sophisticated discussions of the problem of homophonicity and of the importance of tonal distinctions as well as the recognition of a wenyan 文言 vs. colloquial diglossia (Spitzel I660: IO2-IO7), Chinese monosyllabicity is discussed in comparison to Hebrew lexical roots (IO3-IO4), and has its own entry in the copious index (index, p.3). ${ }^{55}$ On the other hand, to use monosyllabicity as a criterion for the proximity to the state of language origins seemed doubtful to some of Webb's contemporaries on the continent, who discussed a less dis-

52 For an insightful "close reading" of Webb’s essay, see Harbsmeier (1995); for the late Renaissance backgrounds and connections to architecture, see Bold (i98I, esp. ch. 3, "Literature").

53 The same label is, incidentally, applied to the Ancient Indians by Herder and Hegel, see Halbfass (1990: 70-7I, 82, 196), although not motivated by linguistic deficit claims proceeding from the absence of linguistic morphology in the Indo-European language Sanskrit.

54 Short histories of the monosyllabicity topos in early European sources on the Chinese language are provided in Ineichen (1987), Schreyer (I992: 24-26) and Luca (2016: 87-9I).

55 On this figure of thought, see also Genette (1976: I36-I37). 
tant Germanic setting. Philipp von Zesen (I6I9-I689), a prolific protestant poet and author of widely successful baroque novels, criticizes Jan van Gorp van der Beke (I5I9I572) in his Rosen=mând (Hamburg I65I) for precisely the idea of a primeval monosyllabicity, he shared with Webb:

It is absurd that Becanus ${ }^{56}$, because he held the opinion that all stem words had to be monomial and had seen that in his Low German mother tongue there were many thousand monomial words, would have liked to conclude and assert that it (Low German) was the first language: since, if this was the case, it would have to be Chinese, which consists completely in monomial words according to the evidence of Scaliger and Lipsius. It may well be true that a stem is tucked into the simplest word and that each word has only one member or one vowel, which indicates the stem to us, and that the stem is self-standing; but who would wish to fathom such a mystery? It is neither human nor feasible. ${ }^{57}$

"Monosyllabic naturalness" still could have a distinctively positive ring for the early Jesuits writing about China such as Matteo Ricci (I552-I6I9), Angelo Rocca (I545-I620) ${ }^{58}$ and authors such as Webb, who directly builds upon them ${ }^{59}$, for instance when he claims that "[T] hey have no letters whereby to express the Privy parts, nor are they to be found written in any of their Books" (Webb I669: 99; cf. Bold 1989: 42-43).

Up to the very end of the French Jesuit mission in Bejing in the eighteenth century, the missionaries occasionally devised clever attempts to account for the apparent monosyllabism of Chinese. Thus, in an anonymous letter from a Jesuit missionary in Beijing from 1764, written to assess (and reject) the similarity between Egyptian and Chinese characters alleged by certain European scholars, the author - possibly Joseph-Marie

56 Bekan is also known under his latinized name Johannes Goropius Becanus or as Jean Becan, a Dutch physician, linguist, and geologist, on whose etymological contributions, see Naborn (I995), van Haal (2010: 77-I40) and Metcalf (2013: 40-44).

57 "Es ist lächerlich/daß Bekan daher/weil er auch in der meinung gewesen/daß die stam-wörter allezeit eingliedrich sein müsten; und gesehen/daß in seiner Nieder-deutschen Mutter-sprache so viel tausend eingliedrige wörter weren/schlüßen und behaupten wollen/ daß sie die erste sprache sei: da es vielmehr/wan diese uhrsache gültig/die Sinische sein würde/welche in lauter eingliedrigen wörtern/nach Lipsens und Skaligers zeugnüsse/ bestehet. Es ist wohl war / daß der stam in den aller einfältigsten stekket / und daß ein iedes wort nur ein einiges glied oder einen selbstlauter hat / der uns den stam weiset / und der stam selbsten ist; aber wer will solches geheimnis überall ergründen. Es ist nicht menschlich / noch möglich” (von Zesen I65I: 210). Cf. the partial quotation and discussion in Roelcke (2017: 229-230).

58 In his first description of Chinese in the epistle to his teacher Martino de Fornari (I547-I6I2) of I3 February 1583 sent from Macau, Rocca stresses: "A questo agiuta che la lettera non tiene articoli, né casi, né numeri, né generi, né tempi, né modi, ma a tutto danno rimedio con certi adverbii che si dichiarano molto bene." [It adds to this that a graph neither has articles, nor cases, numbers, genders, tenses or modes, but to all of this they provide a remedy via certain adverbs, which explain themselves very well] (Luca 2016: 90). On the origins of the European idea of Chinese as a language without morphology, cf. also Luca (2016: I39-I40) and Spence (I988: 44-45).

59 See on Webb’s Renaissance sources Ch'en Shou-yi (1935-36) and Ramsey (I98I: 487-493). 
Amiot (I7I8-1793) or Pierre-Martial Cibot (1727-1780) ${ }^{60}$ (Szczesniak 1952: 29) - defended the poetry of the Shijing 詩經 in the following ingenious fashion:

Some have been inclined to doubt that it [Shijing poetry] was possessed of harmony, being exclusively composed of monosyllabic words. I only have the following to say on this: Those who read our verses best, disconnect, so to speak, the syllables from the words and weigh on each of them in such a way that they almost seem to read only monosyllables. [...] If one examines it well, one would perhaps find that the most essential words were $\&$ are still very short: Ciel, air, eau, feu, mort, main, ail, pied, corps, cœur, dos, pain, fruit, bois, voir, ouir etc. ${ }^{61}$

This quasi-aesthetic strategy of "monosyllabising the Europeans" is restricted here to a particular mode of poetry recitation, but the idea was eventually subject to historical reconstructions as well. This quasi-aesthetic strategy of "monosyllabising the Europeans" to bring them typologically closer to the Chinese is restricted here to a particular mode of poetry recitation, but the idea was eventually subject to historical reconstructions of Indo-European word formation as well, which sought to reduce all recalcitrant lexical polysyllabicity to root etymologies from the mid-nineteenth century. The spirit of the Enlightenment of the two preceding generations in Europe is still tangible in such statements, but it already seems somewhat more defensive than with earlier China scholars such as Étienne Fourmont (1683-1745). ${ }^{62}$ In an explicit reversal of the customary civilized vs. barbarian roles he had urged the intellectual world of his day to learn "exotic" languages such as Arabic in order to overcome their barbarian dispositions:

I cannot point to or value a language more useful than this one, which allows me to traverse Europe, Asia, and Africa in breadth and in length, to the point of making me a citizen of the world and be no longer a barbarian to anyone (Leung, transl. 2002: 74). ${ }^{63}$

Like most other European scholars of his time, Fourmont never doubted that the Chinese language consisted "en monosyllabes prononcez, \& en caractères indépendants

60 On the theory of Amiot as the "last French Jesuit in Beijing", see Hermans (2005: 38-42); on Amiot's life and work, see also de Rochemonteix (I914), Hermans (1993) and von Collani (I988). The theory of an Cibot's authorship is upheld by Szczesniak (1952: 29); for a short biography of Cibot, see also Pfister (1934, II: 890-902).

61 "On a voulu douter qu'elle eut de l'harmonie, étant composée des mots tout monosyllabes. Je n'ai que ce mot à dire. Ceux qui lisent le mieux nos vers, décousent, pour ainsi dire, les syllabes des mots, \& pesent sur chacune, de façon qu'ils semblent presque ne lires que des monosyllabes. Puis! $\mathrm{Q}[. .$.$] Si on l'examinoit bien, peut-être trouveroit-on que les mots les plus essentiels ont été \& sont$ encore fort cours, Ciel, air, eau, feu, mort, main, ail, pied, corps, caur, dos, pain, fruit, bois, voir, ouir \&c." (Anonymous 1773: 4I n. [g]).

62 On whose life and work as a scholar of Hebrew, Arabic and Chinese, see the excellent monograph by Leung (2002).

63 "Utilius autem hac Illa Lingua idicavi aut iudicavi quidquam potest; quo me per Europam, per Asiam per Africam longe lateque circumducat, orbis adeo univeri concivem, Barbarum mortalium nemini" (Bibliothèque Nationale, Mss. Naf 8972, fo II "Discours latin sur la langue arabe, prononcé à mon installation au Collège Royal” I7I5, see Leung 2002: 74 n. 24). 
d'aucune prononciation" ${ }^{64}$ and he toyed around with the idea, that the monosyllables "nous representent en partie les notions des lers hommes"; ${ }^{65}$ but none of that diminished his very positive view of its capacities of expression or reflection. Already during the late Enlightenment, however, syllable structure considerations had become subject to more tenebrous evolutionary schemes. Thus, Johann Christoph Adelung (I732-I806), linguistic typologist avant-la-lettre, ${ }^{66}$ began to integrate them into theories of language origins and development, following the negative turn of the European image of China since the last quarter of the eighteenth century. Otherwise quite well-disposed towards the equality of linguistic means of expression in the dozens of languages he treats in his Mithridates of 1806 , Adelung ${ }^{67}$ writes about monosyllabicity: ${ }^{68}$

[...] it may thus not be astonishing that everything one does or does not know about the origins of the human race, about the formation of the first languages and states, and the first germination of arts and sciences, brings us to West Asia. Egypt, which is said to have hatched all learned and civil knowledge like the chicken in its oven, comes to the fore only later, even if the narrow Valley of the Nile may have benefited the multitudes of the people and the culture founded in it earlier than in some of the wild plains of Western Asia. All these peoples have polysyllabically structured languages, and they do so - as far as one is able to trace them across history - already in remote antiquity. Since nature nowhere takes a leap, it cannot be surmised that it will have transformed at once from the monosyllabic language of a child to the polysyllabic language of a man, several kinds of intermediate levels between the age of the boy and the man will have to be assumed. ${ }^{69}$

64 "Dissertation sur la Littérature Chinoise" (I729: 316), cited in Leung (2002: 174 n. 57).

65 Bibliothèque Nationale, Mss. Naf 8944, fo $176-177$ v., cited in Leung (2002: 170 n. 48).

66 This role is, unfortunately, heavily underappreciated in the contributions to Kämper, Klosa \& Vietze (2008), who barely cite the Mithridates.

67 Adelung already passed away during the year the first volume appeared. It is therefore unclear if the passage reflects his ideas or those of his editor Johann Severin Vater (I77I-I826), or even of the Humboldt brothers with whom he consulted (Stockhammer 2014: 344).

68 Ineichen (1987: 27I) stresses the importance of Adelung for the "canonical" formulation of Chinese monosyllabicity in Europe and the idea of its linkage with the earliest human proto-language. It is unclear, however, what is meant by "canonical". There are few attempts to formally define what is meant by "monosyllabism" in linguistic typology and theory, since they typically hinge upon the definition of even more contentious concepts such as "word" or "morpheme". For a brave, but ultimately unconvincing attempt, see Arlotto (1968).

69 "[...] so kann es nicht befremden, dass man oft alles, was man von dem Ursprunge des menschlichen Geschlechtes, von der Bildung der ersten Sprachen und Staaten, und von den ersten Keimen der Künste und Wissenschaften weiss und nicht weiss, in das westliche Asien versetzt. Aegypten, welches alle gelehrte und bürgerliche Kenntnisse, wie die Hühner in seinen Öfen ausgebrütet haben soll, kommt erst später in Betrachtung, wenn gleich das enge Nil-Thal die Volksmenge und die darin gegründete Cultur früher begünstigt haben kann, als in manchen weiten Ebenen des westlichen Asiens. Alle diese Völker haben mehrsylbige ausgebildete Sprachen, und haben sie schon in dem höchsten Alterthum, so weit man sie nur in der Geschichte verfolgen kann. Da die Natur nirgends einen Sprung thut, so ist auch nicht zu vermuthen, dass sie auf Ein Mahl von der einsylbigen Sprache des Kindes zu der mehrsylbigen des Mannes werde übergegangen seyn, sondern es muss zwischen beyden mancherley Mittelstufen des Knaben- und Jünglingsalters gegeben haben" (Adelung I806-17: 20-2I, cited from Roelcke 2017: 220). 
It follows that almost all cultural or scientific inventions attributed to the "childish" Chinese are subject to doubt and that their language is best described by attributes like "ungebildet" (unlearned), "arm" (poor), or "dürftig" (cloddish). At the turn to the nineteenth century, Adelung did not shy away from downright racist extensions of the monosyllabicity theme when he bemoans that all of their speakers "[...] some more than others have an exceptionally ugly Mongolian physiognomy with flat faces, small and crooked eyes, and blunt noses" (transl. Metcalf 20I3: I64).$^{70}$ It is the Mongols and their repeated invasions of China who Adelung goes on to castigate as the ultimate culprits for the physical side of the monosyllabic blemish (Metcalf 1984: I08), but the alleged linguistic defect emerges as a pan-East Asian phenomenon.

A further topic routinely linked to the early "infantilization" and monosyllabicity discourses is the cumbersomeness of the Chinese writing system. Its acquisition is widely viewed as so time consuming that its mastery effectively prevents the Chinese from all other intellectual activities. Elaborating on the writing system as "a wall that God wanted to stand between them and us" (la muralla que Dios quisso que aya entre ellos y nosotros), and which "those who call themselves literati spend their lives on learning exclusively this" (gastan la bida los que se llaman letrados en aprender solo esto), the Jesuit Alonzo Sánchez (I547-I593) already wrote in I583:

And the devil's intervention has been such to coerce their judgment and to occupy them in the understanding that what one of our children learns within a year or a year and a half during childhood, they do not even manage in all of their life, so that they do not learn other languages or other sciences of the natural or supernatural things, or laws and moral things $[\ldots]$ because of the great difficulty of their letters (Luca 20I6: IOI-2, transl. mod. auct.). ${ }^{71}$

From here, the line to Johann Gottfried Herder's (I744-I803) conceptualization of the Chinese empire as "a house of virtuous, well-behaved, diligent, demure and happy children and brothers" (ein Haus tugendhafter, wohlerzogener, fleissiger, sittsamer, glücklicher Kinder und Brüder) ${ }^{72}$ in the eighteenth century is very short. The reason, according to Herder, why all cultural expressions of the Chinese have "for centuries stayed children of their own laws and of their unalterable childish disposition" (seit Jahrhunderten Kinder ihrer ewigen Gesetze und unabänderlich kindischen Einrichtung) and that they live in a "childlike imprisonment of reason, power and sentiments" (kindische Gefangenschaft der Vernunft, Kraft und Empfindung) is, again, to be sought in the writing system:

70 "[...] manche mehr, manche weniger, die ausgezeichnete hässliche Mongolische Bildung mit platten Gesichtern, kleinen, schief stehenden Augen und stumpfen Nasen" (Adelung I806-7: 32).

71 "Y ha sido tal la ynvención del demonio para cojerles el juicio y ocuparles en el entendimiento, que lo que un niño nuestro aprende en un año o año y medio en la nińez, hacen ellos ni por toda la bida, con lo que ellos no aprenden otras lenguas o otras sciencias de las cosas naturales o sobrenaturales y las leyes y cosas morales [...] por la grande dificultad de sus letras" (Sánchez 1583, quoted in Luca 20I6: IOI-2).

72 Ideen zur Philosophie und Geschichte der Menschheit XI.3 (1787, quoted in Merkel 1942: 7). 
The difference with which this type of writing affects just the soul which thinks in it alone must be incredible. It unnerves thoughts into painting traits and the whole nation into random characters, painted or written into the air. ${ }^{73}$

The same verdict reaches its most forceful and reverberant European consolidation in the whole gamut of negative predicates which Hegel holds ready for China: absence of "inwardness" (Innerlichkeit), of history, of an autonomous conscience, of immanent reason and true individuality and so on. ${ }^{74}$ And it does not stop, as Heiner Roetz has pointed out on many occasions (e.g. Roetz 1984: 17-29; 1992: 23-29), in the nineteenth century, even if we limit ourselves to the discourse on the writing system. ${ }^{75}$

\section{Antimonosyllabism}

Given this long-standing European background Lacan can hardly be blamed for falling prey to the widespread "monosyllabic myth" (Kennedy 195I) as well. It was probably still shared by Demiéville and most other language teachers at the "Langues O" during the Nazi period. One of the very few early European scholars of Chinese who escaped this idea was Gottlieb ("Theophilus") Siegfrid Beyer (I694-I738), the famous orientalist, sinologist and historiographer from Königsberg. ${ }^{76}$ In his Museum Sinicum of 1730 he had identified monosyllabicity as a misperception based on the writing system:

Now if you consider everything carefully, the Chinese still have polysyllables, but since they distinguish the syllables through characters, we regard them as monosyllables. ${ }^{77}$

Among the sinologists of the nineteenth century, this idea, mentioned only in passing by Beyer, was seriously considered by Jean-Pierre Abel-Rémusat (I788-1832), the leading French sinologist at the Collège de France. The increased knowledge of varieties of spoken Mandarin with its different word/morpheme to syllable ratio as opposed to the Classical language undoubtedly contributed to this new perspective. Rémusat elaborated on monosyllabicity in a very interesting essay entitled "Utrum Lingua Sinica sit vere monosyllabica? Disputatio philologica, in qua de Grammatica Sinica obiter agitur" (Is the Chinese language really monosyllabic? A philological disputation, in which the Grammar of Chinese is treated in passing) (Rémusat I8I3, Bourgeat, transl., I8I4). In it, he provides a whole series of the kind of examples still used today to doubt the idea that

73 "Unglaublich muß der Unterschied sein, mit dem diese Schriftart allein schon auf die Seele wirkt, die in ihr denkt. Sie entnervt die Gedanken zu Bilderzügen und macht die ganze Nation zu gemalten oder in die Luft geschriebenen willkürlichen Charakteren" (ibid., quoted in Merkel I942: 9).

74 Hegel's views on China are collected and commented upon in great detail in Wittfogel (I93I), Merkel (1942), Schickel (1970), Roetz (1984), Lee (2003: 274-319) and Lo (1994), so that we can forego a further discussion here.

75 For a masterful criticism of a whole series of twentieth century extensions of this topos, see the section on "Indifferenz von Präsenz und Repräsentanz - die 'ideographische' Schrift" in Roetz (2006: 17-19) and McWhorter (2016: 73-103, "Dissing the Chinese").

76 On Beyer's wide-ranging contributions on oriental subjects, see Babinger (1915); on Beyer as a sinologist, cf. Lundbaek (1986).

77 "Quaere si recte omnia consideres, Sini adhuc habent polysyllaba, sed quia distinguunt syllabas characteribus, habentur pro monosyllabic" (Beyer 1730: 106). 
all Classical Chinese morphemes were monosyllabic. He notes that "names of quadrupeds, birds, fish, worms, trees, herbs and and a good number of inanimate things are expressed by polysyllabic terms [...]."78 And he underscores the existence of what would be later called "phonologically correlated characters" (lianmian zi 聯綿字) in China, or "binomes" in Western sinology, where the constituent parts rhyme and/or alliterate. Proceeding further, he dwells upon characters which are meaningless, unless entering into composition or, conversely, loose their meaning in compounds, like -fu 佛, known to him only as a character, "quo Sinae nomen Dei Buddha breviter reddere conati sunt" (which the Chinese have made use of to abbreviate the name of the God Buddha) (I8I3: 280), in fangfu 仿佛 “as if; resemble", and which, moreover, occurs in various other orthographies such as fangfu 䯮髹, fangfu 㑂佛, fangfu 放费, fangfu 放弗, fangfu 彷 彿, fangfu 方弗. ${ }^{79}$ He points to disyllabic adverbs suffixed by -ran 然, noun suffixes like $-z i$ 子, -tou 頭 or -ren 人, plurality markers like zhong-衆, -men 們, and -deng 等; and he doesn't fail to mention onomatopoeia, adverbial reduplications, loanwords, especially from neighbouring "Altaic" languages either. Finally, he illustrates the considerable frequency of disyllabic words by a translation of the Lord's prayer into Literary Chinese. The cited affixation patterns constitute ample evidence for Rémusat, that the idea - so forcefully propagated by the missionaries in the century preceding him - that Chinese had no grammar to speak of, was entirely mistaken. ${ }^{80}$

While Rémusat's lively discussion with Wilhelm von Humboldt (I767-I835) on the "genius of the Chinese language" has meanwhile been well-studied, ${ }^{81}$ since it had such profound influences on the philosophy of language in (and outside) sinology, the reception and elaborate rejection of Rémusat's anti-monosyllabism by Friedrich Wilhelm Joseph Schelling (1757-I854) in his Philosophie der Mythologie of I856 has so far received less attention. ${ }^{82}$ Like many of his contemporaries, Rémusat had associated monosyllabism with a "barbarian" stage of development, from which, however, the cultivated Chinese had long emancipated themselves, concomitant with the growth of polysyllabism in their language. Against this heretic view - so heretic, indeed, that it became the subject of news articles in some important papers at the time ${ }^{83}-$ Schelling argues, quite

78 "[n]omina fearum, avium, piscium, vermium, arborum, herbarum, rerumque inanimarum complurium, vocibus polysyllabis exprimuntur [...]" (Rémusat I8I3: 285).

79 These are listed in a plate included in Rémusat ( 1813 , after 208), but dropped from the passage in the French translation (I8I4: 98-99). Cf. also Drocourt (2OI3: I2-I3).

80 De Rémusat had inherited this perspective, it seems, from his Parisian predecessor Fourmont, who, like him, had never been to China. For Fourmont's forceful defense of the necessity of basing the interpretation of scripture on "the laws of grammar", see Leung (2002: 108, cf. I89).

81 See e.g. Harbsmeier (1979), Chevalier (1979) and Thouard (1999).

82 Schelling's lengthy reflections on the Chinese language and script appear mostly in lecture 23 of his Philosophie der Mythologie of I856 (Schelling I856: 52I-555); for a convenient reprint, see Hsia (I985: 2II-227). A synopsis of the very difficult work is presented in Hösle (2013: 447-450); two general summaries of Schelling's view on China include Fang Weigui (1992: 13I-I37) and Hsia (2002).

83 See, e.g., the Leipziger Literaturzeitung Vol. 35.305, I6 December I8I4: 2434; Wiener Allgemeine Literatur-Zeitung, Vol. I04, April I816: 522; Jenaische Allgemeine Literatur-Zeitung Vol. 91.I9I, October I8I9: IOo. 
apodictically, that wordhood in Chinese is completely underspecified: the single word is "seemingly nothing" (gleichsam nichts), such that it does not have "the freedom to spread out" (die Freiheit, sich auszubreiten) (Schelling 1856: 544). Wordhood in Chinese is thus purely compositional, the underlying "atoms of words of the Chinese language have emerged only via abstraction" (Wortatome der chinesischen Sprache sind erst durch Abstraktion entstanden) (ibid.). Against this background, it is therefore incorrect to say,

[...] that the Chinese language consists of monosyllabic words. By doing this, one presupposes something which essentially does not take place, since, as stated above, word forms are not meaningful words, they are just traces or moments of speech, and therefore merely sounds or tones, to which no independence vis-à-vis language can be assigned, as if they were something on their own. They are just elements, which acquire their meaning from the whole. ${ }^{84}$

According to Schelling, this "atomistic" nature, coupled with a lack of external form, necessitates strict linear ordering to achieve the semiosis of the lined-up elements, and inevitably results in the "nervous brevity of the oldest Chinese books" (die nervöse Kürze der ältesten chinesischen Bücher). By consequence, written Chinese is the "most crammed language in the world" (die gedrungendste Sprache der Welt) in which, according to the Jesuits, the thoughts appear "as if chocked together" (wie ineinander gekeilt) (Schelling 1856: 546). Where the word has not been "unleashed into independence" (zur Selbständigkeit entfesselt), where it is "still too introvert, to be an object of reflection" (zu innerlich, um Gegenstand der Reflexion [...] zu sein) (ibid.: 546-547), the language must be close to the primeval state of an Ursprache. Pushing the argument to its limits, he goes on to claim that it is not a language at all:

The pure materiality of the primaeval language has not been maintained in Chinese, yet the sidereal power of it well has. For us, Chinese is like a language from a different world. And if one tried to provide a definition of "language" on the basis of the meaning at play when other idioms are referred to as "language", one would end up with the necessity of admitting that the Chinese language is not a language at all, just like Chinese mankind is not a Volk. ${ }^{85}$

Von Humboldt's interest was in a comparative and ultimately deterministic typology of the ways in which linguistic forms condition the shape of meaning, and, by consequence the emergence of (philosophical) thought. His ascription of analogy as the prevalent

84 "[...] daß die chinesische Sprache aus einsylbigen Wörtern bestehe, man setzt dabei etwas voraus, was im Grunde gar nicht stattfindet; denn, wie gesagt, die Worte sind eigentlich keine Wörter, sie sind nur Spuren oder Momente der Rede, und ebendarum bloße Laute oder Töne, denen gegen die Sprache gar keine Selbständigkeit zukommt, als wären sie etwas für sich; sie sind nur Elemente, die ihre Bedeutung vom Ganzen erhalten" (Schelling I856: 544).

85 "Das rein Materielle der Ursprache ist im Chinesischen nicht erhalten, wohl aber die siderische Kraft derselben. Das Chinesische ist für uns wie eine Sprache aus einer anderen Welt, und wenn man eine Definition der Sprache nach dem Sinn geben wollte, in welchem die anderen Idiome Sprachen heißen, so würde man in die Nothwendigkeit kommen zu gestehen, daß die chinesische Sprache gar keine Sprache ist, wie die chinesische Menschheit kein Volk ist" (Schelling 1856: 548). 
"thought formation" (Denkform) to Early China corresponds to his observations about the isolating nature of the Chinese language. Schelling, on the other hand, seems more worried about the idea that the radices of those languages important for the early development of European philosophy and religion, like Biblical Hebrew, could be reduced to a monosyllabic state of origins as well. This would be, he claims, merely a "fashion (and nothing more than that) [...] which is due to an admiration of Chinese" (Schelling I856: 544) ${ }^{86}$ Parallel, in a sense, to Hegel's (in)famous "lack of inflection = lack of reflection" equation (Roetz 2006: 29), the animus of his argument is a somewhat different juxtaposition linked to the question of theogony:

[...] as paradoxical as this statement may seem outside its context, as evident it is within the whole issue of our inquiry that the polysyllabism of a language and polytheism are simultaneous, concomittantly posited, parallel phenomena. ${ }^{87}$

Just like the Chinese of his great adversary Hegel are outside the realm of world history, in a state of childlike, primaeval beginnings, Schelling's Chinese are even outside the realm of mythology and religion. To their complete "negation of movement" (Schelling I856: 557) corresponds a defective language, whose speakers are not only incapable of pronouncing an $R$; even worse, they cannot even say "Klistus statt Christus" (Schelling I856: 545), because they have to split up all consonant clusters inserting an anaptyctic vowel. The all-domineering powers of monosyllabicity coupled with contour tones, ${ }^{88}$ he argues, are subjugating the language like

[...] a magnetic stream [which] puts all elements of language into order, as if holding them in captivity, but which, at the same time, inserts them into such a relationship that one element becomes a necessary complement of the other, that one carries and maintains the other, like every tiny piece of ferrous dust magnetically ordered along the iron rasp only exists in this whole and possesses no existence beyond that very moment. ${ }^{89}$

Schelling wrote some seventy years after Sir William Jones' (I746-I794) “discovery” of the genealogical relationship between Indo-European languages, ${ }^{90}$ a good decade after

86 Schelling knew Hebrew well. He had studied it as a teenager along with Arabic under his father, a lecturer in Oriental languages in the monastic college of Bebenhausen near Tübingen (Hösle 20I3: $43 \mathrm{I})$.

87 "[...] so paradox dieser Satz außer seinem Zusammenhang erscheinen würde, so einleuchtend ist in dem Ganzen unserer Untersuchung, daß der Polysyllabismus der Sprache und der Polytheismus gleichzeitige, miteinander gesetzte, parallele Erscheinungen sind" (Schlegel I856: 547).

88 Curiously the referee for information about the tonal system is Sir William Jones, "who certainly had several occasions to hear Chinese speak on account of his longer stay and his position in India" (Schelling I856: 545).

89 "[...] ein magnetischer Strom [der] alle Elemente der Sprache ordnet und gleichsam gefangen hält, aber zugleich in ein solches Verhältnis setzt, daß eines den anderen zur notwendigen Ergänzung wird, eines das andere trägt und hält, wie jedes Stäubchen der magnetisch geordneten Eisenfeile nur in diesem Ganzen ist und für den Augenblick kein Seyn außer demselben hat" (Schelling 1856: 546).

90 In the sense of its Wirkungsgeschichte in the history of linguistics. Systematic similarities between Sanskrit and Classical European languages had long been noticed by a number of scholars since the 
Eugène Burnouf (I8OI-I852) had established the Indo-Persian sound correspondences through his study of the Late Avestan Vîdêvdâd (Burnouf I829-I843), and just a few years after the last fascicle of Franz Bopp's (I79I-1867) monumental Comparative Grammar had erected the edifice of the Indo-European language family in terms of regular sound laws (Bopp I833-I852). ${ }^{91}$ He was well aware that he could not simply condone Rémusat's association of monosyllabicity with "barbarism", although he seems at times to struggle with that decision. For the equation "Barbarei = Kindheit" (Schelling I856: 549) from which Chinese had, according to the French sinologist, long evolved towards a polysyllabic maturity, not only posed problems on the Chinese side. On the one hand, such a view ran into trouble in view of polysynthetic or "incorporating" languages, no longer a complete linguistic terra icognita in the middle of the nineteenth century. Humboldt and other linguistic typologists avant la lettre had long shown that "[...] the overly long words of the American aborigines [...] which surely have a well-founded claim to the designation barbarian people" occur in languages which "have surrendered themselves to a senseless polysyllabism" (Schelling 1856: 549). On the other hand, Schelling's system also needed to account for the polytheism of the Vedic Indians despite their Indo-European linguistic pedigree, and to accommodate his idea of an Indo-European monotheistic first religion, which had soon deteriorated. Using the same swift figure of thought by which he had denied the existence of a Chinese humanity on account of a direct denial of their language in the area of mythology and religion, he simply decrees, in a quasi-tautological fashion:

If one takes away the polysyllabic quality of a language, it ceases to be that language [...] just like the Indian, whose mythology one traces back to a primeval monotheism, ceases to be an Indian, because he is Indian just exclusively on account of his polytheism. ${ }^{92}$

It is interesting to note that roughly at the same time, Joseph Arthur Comte de Gobineau (I816-I882), one of the ancestors of Aryan racism, was much less convinced of the possibility of correlating monosyllabism with a particular kind of inbred or inherited intellectual disposition. In his Essai sur l'inégalité des races humaines of 1853 he writes:

It seems to me, then, that monosyllabism can occur in all linguistic families. It is a kind of frailness determined by accidents of a still unknown nature, not a specific trait capable of

sixteenth century, cf. Halbfass (1990: 63), App (2009: 46 n. 45); a notion of regularity of sound change is already evident in Claudio Tolomei's (I492-I555) treatment of Latin cluster developments into Italian (McDavid 1990). For some nice specimens from the history of comparative linguistics in Europe from Giraldus Cambrensis (II46-I223) up to Sir William Jones, see Campbell (2017: IOO-IO2).

91 Burnouf's work on this connection is crucial for Schelling's interpretation of Buddhism as reflecting a dualist orientation inherited from Zoroastrism, see Schelling (I856: 508-5I0).

92 "Nimmt man dieses Mehrsylbige einer Sprache hinweg, so ist sie überhaupt nicht mehr diese Sprache [...] gerade so wie der Indier, dessen Mythologie man auf einen Urmonotheismus zurückführt, nicht mehr Indier ist, denn Indier ist er gerade nur durch seinen Polytheismus" (Schelling 1856: 544). 
separating a language which is clad in it from the rest of human languages, by affording a special individuality to it. ${ }^{93}$

In China itself, the association of monosyllabicity with ethnic Chinese (i.e. "Han 漢”) identity seems first to have arisen long before the period of Chinese-European contacts during the Chinese Völkerwanderung of the Early Medieval period in the specific domain of surnames. Thus, the History of the Wei Dynasty finished in 554 C.E. reports from the taihe 太和 reign $(227-233 \mathrm{CE})$ that "two-syllable names were changed into one syllable names” (Weishu 魏書 2: 23). Two-hundred years later, the abandoning of two-syllable names, was one of the most prominent measures in the siniciziation movement spearheaded by the Northern Wei emperor Xiaowen 孝文 (r. 47I-499), né Tuoba Hong 拓 拔宏. ${ }^{94} \mathrm{He}$ also prohibited the para-Mongolic Xianbei 鮮卑 language of his ancestors, and enforced "the abandonment of Hsien-pei costumes for Chinese-style attires, and the full-scale adoption of Chinese rituals and legal code" (Ho Ping-ti i998: I3I).

The heretic idea - then and still today - that Old Chinese may not have been exclusively monosyllabic, despite the fact that all modern Sinitic languages have overwhelmingly monosyllabic morphemes, was probably first articulated in Chinese in an essay by the "national essence" (guocui 國粹) movement philologist and philosopher Zhang Binglin 章炳麟, entitled "A theory that one character corresponds to doubled sounds" (“Yi zi chong yin shuo"一字重音說). ${ }^{95}$ It is unclear how much it was influenced by the earlier European discussions we have just reviewed. Zhang's theory was unpopular already during the Republican period and had little impact on the development of mainstream historical phonology in China during the twentieth century (and often beyond). It was inhibited by the “tetragraph" (fangkuaizi 方塊字) nature of evenly spaced characters ${ }^{96}$ without blanks and punctuation in traditional Chinese writing, ${ }^{97}$ which create the strong impression of a coalescence between syllable, morph, and graphical unit in the writing system. The perception of this unity, alternatively mentioned with wonder or derision in almost every major European account of the Chinese language from the seventeenth century, has also been argued to constitute the primary mechanism behind

93 "Il me paraît donc que le monosyllabisme peut se présenter chez toutes les familles d'idiomes. C'est une sorte d'infirmité déterminée par des accidents d'une nature encore inconnue, mais point un trait spécifique propre à séparer le langage qui en est revêtu du reste des langages humains, en lui constituant une individualité spéciale” (Juin, ed., I867: I80 n. I).

94 Cf. Beishi 北史 (88: 1020).

95 The essay was included in his famous Disquisitions on National Heritage (Guogu lunheng 國故論衡) of I919. For the evidence and backgrounds of this pathbreaking formulation, see Zhao Dan (2OII). On the interesting model of language origins underlying this theory, see also Kaske (2008: 352-366).

96 Building upon information first described by the Armenian monk Hayton of Corycos (Het'um, ca. I245-I3I4) in his history dictated in 1306 to Niccolo Falconi, the German humanist Johannes Boehmus (Hans Böhm, I485-I535) was apparently the first person in Europe to talk about "literis utuntur Romanis quadratura similibus" (Luca 2016: 29).

97 Note, however, that Old Chinese manuscripts did have quite a few of punctuation marks, mostly inserted by the readers. For a comprehensive overview, see Guan Xihua (2002). For a discussion of their wider significance, see also Behr \& Führer (2005) and Richter (2017 [2015]). 
the origins of writing in Sumerian and Chinese ${ }^{98}$ since Heymann [Chajim] Steinthal's (1823-1899) Die Entwicklung der Schrift, nebst einem offenen Sendschreiben an Professor Pott (The development of writing, including an open epistle to Professor Pott) of $1852 .{ }^{99}$ Today, there is finally some good evidence from computational modelling that "the development of writing systems ex nihilo" seems indeed "to be facilitated in languages that have largely monosyllabic morphemes, or that have abundant ablauting processes" (Sproat 20I7).

Meanwhile, however, many state-of-the-art models of Old Chinese syllable structure since the I990s have returned to Zhang Taiyan's idea, mostly without being aware of it. They hold that a considerable number of Old Chinese words were one-and-ahalf syllables long (sesquisyllabic) and had a "iambic" prefixation pattern of reduced pre-syllables, also typical of many Austroasiatic and Tai-Kadaiic languages. ${ }^{100}$ Thus, while the dominant texture of Old Chinese was monosyllabic, a sizeable segment of the lexicon was not. Languages are, as we feel confident to state since the formulation of George Kingsley Zipf's (1902-1950) "principle of least effort", typically characterized by an "economy principle", especially in the area of (mor)phonology. ${ }^{101}$ If that is the case, a good theory of Old Chinese will have to explain the presence of those words, where a monosyllabic lexical root is extended by half a syllable, attached to the root with a reduced "schwa-vocalized" vowel. It is reasonable to assume that the pre-syllables now reconstructed for Old Chinese will have carried "functional load", that is to say, the initial consonants of such pre-syllables and of consonant clusters will in all likelihood have encoded grammatical information. And it follows that Old Chinese must have had a considerable amount of derivational morphology (Sagart 1999; Jin Lixin 2002; Baxter \& Sagart 20I4) as well as, very likely, a moderately agglutinating typology. Moreover, since

98 Mesoamerican systems would be added to the Sino-Egyptian pair only slightly later, see Pellery (1992) and Hamann (2008) for the history of this association.

99 Steinthal, now mostly remembered as the editor of W.v. Humboldts work, as a philosopher of language and as one of the most wide-ranging linguistic typologists, had studied Classical Chinese with Stanislas Julien (1707-1873) in Paris and received his second "Prix Volney" in I852 with a treatise entitled "Zur vergleichenden Erforschung der chinesischen Sprache" which remained unpublished until the recent manuscript edition of Edmondson (Steinthal I854 [1999]); see Edmondson (1999). The same idea reappears in von der Gabelentz (2016 [1891]: 136), whose conceptions of the language/writing relationship, however, changed quite dramatically throughout his career (cf. Friedrich 2004). Contemporary reformulations of the monosyllabicity principle underlying logography include Daniels (1992), Boltz (2000) and Buckley (2008), all unaware of their early Saxonian predecessor.

100 For various competing theories of sesquisyllabicity, see Pan Wuyun (1998), Sagart (2004 [1999]: I3-20), Jin Lixin (2002: I-I6) and Baxter \& Sagart (2014: 50-52).

101 The principle is most prominently enshrined in André Martinet's (1908-1999) Économie des changements phonétiques (Martinet 1955). There are many predecessors of the underlying insight, which has enjoyed a persistent afterlife in linguistics up to the present day, nicely sketched in Vicentini (2003). Needless to say, there are many examples which do not conform to the economy principle as well. For some charming ones, see McWhorter (2016) or many of the items collected in Plank (2000-); for attempts at formal refutations of paradigm economy in morphology, see Nyman (1986), and of economy conditions in various (anti-)generative syntactic theories, Potts (2002). 
it can be shown on the basis of unsystematic remnants reflected in Old Chinese texts that this morphology was obsolescing quite early, the compensating process of disyllabification via compounding must have started much earlier than traditionally assumed. ${ }^{102}$

It may be interesting to note that these insights, increasingly consolidated by the tremendous progress in the reconstruction of Old Chinese phonology and morphology since Bernhard Karlgren (I889-1978) and his many twentieth and twenty-first century successors, were already prefigured in the theory of agglutination-inflection-isolation "spirals" of Georg von der Gabelentz' (I840-I893), undoubtedly the most insightful scholar of Chinese grammar of his generation. In the very influential summa of his lifelong work on general linguistics, Die Sprachwissenschaft (Gabelentz 2016 [I89I]), he stresses that Chinese - despite the ancient attestation of writing and literature - seems "much more threadbare than many of its younger sisters" (schon weit abgenutzter [...] als viele ihrer jüngeren Schwestern; Gabelentz 20I6: I68 n.*). In this respect, he argues, Chinese offers a neat parallel to Ancient Egyptian as the oldest attested Afroasiatic language which is characterized by many innovative morpho(nolo)gical traits vis-à-vis Semitic:

And the two most ancient languages of civilization, Chinese and Egyptian, are characterized already in their oldest monuments by a considerably more blurred and modern distinctiveness than their younger relatives. Thus the historian is bound to witness that the age of the oldest documents is almost inversely proportional to the antiquity of the languages in two different historical instances. ${ }^{103}$

If one takes the antiquity of written attestations out of the framework of comparison, the relationship is thus akin to English vis-à-vis Germanic or French towards Latin, such that Chinese would have to be classified as the most radically innovative language in the family we call "Tibeto-Burman" today. ${ }^{104}$ Extending his observation to all isolating languages of East Asia he continues:

We may only come up with a highly tentative notion of the quality of the most ancient phonological forms (words) of human language. In the past it was believed, they must all have been one syllable long and immutable. Pointing to the monosyllabic isolating languages of Eastern Asia, e.g. the Chinese, Siamese, Annamite, it was even claimed that they had stayed behind in that primeval developmental state. The latter assumption may

102 The latter position was already formulated by Dubs (1952). For an update on the technical knowledge we have about the monosyllabism issue today, see Michaud (2012), Behr (2015b) and Salmons \& Zhang (2018).

103 "Und zwei der ältesten Cultursprachen, die chinesische und die ägyptische, tragen schon in ihren frühesten Denkmälern ein weit verwischteres, moderneres Gepräge, als ihre jüngeren Verwandten. So muss es der Geschichtsforscher an zwei verschiedenen Stellen erleben, dass das Alter der ältesten Urkunden zu der Alterthümlichkeit der Sprachen fast im umgekehrten Verhältnisse steht" (von der Gabelentz 2016: 298).

104 Von der Gabelentz still uses the designation "Indo-Chinese" for a family thought to comprise not only Sino-Tibetan but also Tai-Kaidaiic languages. 
be considered refuted today; one might rather assume that these languages are especially developed. ${ }^{105}$

While he does not deny that the oldest layers of Chinese four thousand years ago were already monosyllabic and isolating, and although he criticizes ${ }^{106}$ others who claim the contrary (270, n.*), he admits that Early Old Chinese "contained traces of an older agglutinative, possibly inflectional stage" (wennschon mit Spuren eines älteren agglutinativen, vielleicht flexivischen Zustandes behaftet, von der Gabelentz 2016: 270). ${ }^{107}$ Long before Henri Maspéro's (I883-1945) seminal article on remnants of derivation in Old Chinese word families (Maspéro 1930), commonly held to be the beginning of this fruitful reorientation towards morphology in the study of the Chinese language, von der Gabelentz had already pointed to reading variants of the type 好 hăo "be good": hào "be good to, love", 先 xī̄n "earlier, before": xiàn "go ahead, lead" or 王 wáng "king": wàng "be king of, reign over" as a phenomenon "in all likelihood non-original but due to the effects of a lost affix" (Gabelentz 2016: 400). ${ }^{108}$ Similarly, some forty years before Karlgren's idea that the Old Chinese system of pronouns reflected the residue of a lost pre-Old Chinese inflectional paradigm, von der Gabelentz had confidently stressed that the pronoun variation, "loin d'être arbitraire, dépend des fonctions syntactiques de ces pronoms" (Gabelentz I88I: 292). Thus, for von der Gabelentz, the isolating nature of the language of the earliest Chinese documents is "tertiary, possibly even quarternary" (Gabelentz 2016: 365; cf. also 270). This is also borne out by the other diachronic end of the morphological typology spiral ${ }^{109}$, which features rampant compounding to compensate for the fact that Old Chinese may "hardly be considered to be monosyllabic-isolating" any longer. ${ }^{110}$

Only a few years later, the champion of Sino-Bablyonianism Terrien de Lacouperie held a similar position (Terrien de Lacouperie 1889) and it is unclear, who learned from whom (if at all). He claimed that:

105 "Von der Beschaffenheit der ältesten Lautkörper (Wörter) der menschlichen Sprache können wir uns nur eine unvollkommene Vorstellung machen. Früher nahm man wohl an, sie müssten allesammt einsylbig und unveränderlich gewesen sein, man führte die monosyllabisch isolirenden Sprachen des östlichen Asiens, die chinesische, siamesische, annamitische an, behauptete wohl gar, die wären auf jener Urstufe sitzen geblieben. Das Letztere darf heute als widerlegt gelten; eher mag man annehmen, es seien jene Sprachen besonders weit fortgeschrittene" (von der Gabelentz 2016: 268-269).

106 Possibly with a tongue-in-cheek nod to Terrien de Lacouperie, see below.

107 Notice that in his inaugural lecture he had still characterized concepts such as "agglutinating" as "[...] little more than a cache-désordre, a big scientific junk room (Rumpelkammer) in which radically different forms of language are preliminarily stored like the different meadow grasses in hay" (von der Gabelentz I88I: 287).

108 Indeed, these contrasts, now usually referred to as “qusheng 去聲 ('departing tone') derivations”,

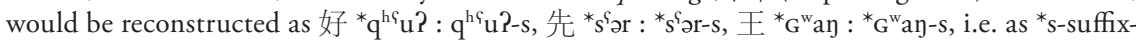
ations today (cf. Baxter \& Sagart 20I4).

109 On von der Gabelentz's spiral theory of morphological typology, see also Gasde (I993: I4I-I43) and Bartschat (1996: 89-90).

110 "[...] kaum mehr als monosyllabisch-isolirend gelten können", von der Gabelentz (2016: 365). 
The phonetism of the language has been greatly altered, but its morphology has changed little. The archaic language, like the modern, had its bisyllabic and trisyllabic words as well as monosyllables; it was agglutinating in a way perhaps more sensitive than the dialects of today, because its phonetic system was less altered [.... . . ${ }^{11}$

Many words now monosyllabic come from the fusion of two syllables that were once distinct in speech and writing. ${ }^{112}$

Pushing the idea even further, he goes on to explain that many pre-unification characters (guwen 古文) reflect polysyllabic words which one may still find as remnants in some spoken dialects. What he seems to have in mind here are ligature writings (hewen 合文) and the strategy of reading characters in a way I have elsewhere called "phonanalytic-intrasyntactic" (Behr 2009: 30I) - that is, by combining character elements into a linear phonological and propositional chain, as in the well-known Modern Chinese example béng 有 'need not,' which is transparently derived from bu 不 'not' and yong 用 'use, need'. Unfortunately, the treatise he self-confidently announced on the topic and the way the principle would systematically explain metrically irregular lines in the Odes, never seems to have appeared:

By reading the same complex word-characters which one finds in archaic poetry, it is possible, as we will show in a special paper, to find the original five, six, or seven footed verses and their corresponding rhymes, instead of the forced and often impossible tetrasyllabic rhymes through which we read those same verses today. In short, the archaic Chinese language has never been a language of roots or monosyllables $[\ldots] .{ }^{113}$

We can see that three of the most important scholars of Chinese in the eighteenth and nineteenth century, Abel de Rémusat, Terrien de la Couperie and von der Gabelentz, all agreed on the secondary nature of Chinese monosyllabicity, but the opposite stereotype was already too deeply entrenched to be overturned by them.

\section{Antilogocentrism}

Another topic which has been called the prejudice of the Chinese ideogram comme pure mimésis by Madeleine David (1965: 66; cf. Genette 1976: 67, 389) proved to be just as persistent as that of monosyllabism. As Genette perceptively stated long ago:

111 "Le phonétisme de la langue a été largement altéré, mais sa morphologie n’a que peu changé. La langue archaïque, comme la langue moderne avait ses mots bisyllabiques et trisyllabiques aussi bien que des monosyllabes; elle était agglutinante d'une manière plus sensible peut-être que les dialectes d'aujourd'hui, parce que son système phonétique était moins altéré [...]" (Terrien de Lacouperie I889: 257).

112 "Nombre de mots maintenant monosyllabiques proviennent de la fusion de deux syllabes autrefois distinctes dans la parole et l'écriture” (ibid.: 259).

113 "II est possible, ainsi que nous le démontrerons dans un mémoire special, de retrouver par la lecture de ces mêmes mots-caractères complexes que l'on rencontre dans la poésie archaïque, les vers originaux de cinq, six, sept pieds et leurs rimes correspondantes, au lieu des quatre syllabes à rimes pénibles et souvent impossibles par lesquelles on lit les mêmes vers aujourd'hui. En résumé la langue archaïque chinoise n’a jamais été une langue de racines ou de monosyllabes [...]" (Terrien de Lacouperie I889: 259). 
"Throughout the 2oth century and in accordance with the same mirage, the Chinese logogram plays the role of a confirmatory myth and exotic warrantor which was played by the "hieroglyph" before Champollion." 114 When Lacan comments, on I4 May I969, on writing as a "system" divorced from the voice, he thus stands - consciously or not - in a long tradition of European conceptualizations of logographic writing:

It is certainly crucial for the correct evaluation of what goes on in a linguistic system (langage) to place an emphasis on the script, and on the fact that the script is primary and must be considered as such in terms of what constitutes speaking (parole). This is, after all, something which may not only be considered lawful but something which is rendered obvious by the mere existence of a script like the Chinese, where it is clear that what is of the order of the apprehension of the gaze is not irrelevant to what is translated of it onto the level of the voice, namely, that there are phonetic elements, but that there are also many elements which are not. This is all the more striking in that - from the point of view of structure, of the strict structure of what constitutes a linguistic system (langage) - no individual language (langue) holds itself together in a purer way than that Chinese language, in which each morphological element is reduced to a phoneme. It is thus striking to see that precisely there, where it would have been the simplest, if I may say that, that the script only functioned as a transcription of what is expressed in words, that, quite to the contrary, the script, far from being a transcription, is another system, a system to which eventually clings what is cut off from another medium - that of the voice. ${ }^{115}$

Looking at his insistence of writing as un autre système one also suspects that Lacan had at this point already read Derrida's De la grammatologie, first published in 1967, whose sustained campaign against European logocentrism had initially also drawn inspiration from Freud's theories of writing. ${ }^{116}$ Happily setting aside all major Anglo-American approaches to the philosophy of language since Wittgenstein, Derrida's path to the traces of logographic writing in Egypt and China and out of the alleged "phonocentrism" and "metaphysics of presence", carries all the heavy baggage of Jesuit conceptions of the

114 "Le logogramme chinois joue typiquement au XXe siècle, et selon le même mirage, le rôle de mythe confirmatif et caution exotique que jouait avant Champollion le 'hieroglyphe' égyptien" (Genette 1976: 389).

115 “Assurément l'accent à mettre sur l'écriture est capital pour la juste évaluation de ce qu'il en est du langage, et que l'écriture soit première et doive être considérée comme telle au regard de ce qui est la parole, c'est ce qui après tout peut être considéré comme non seulement licite mais rendu évident par la seule existence d'une écriture comme la chinoise où il est clair que ce qui est de l'ordre de l'appréhension du regard n'est pas sans rapport à ce qui s'en traduit au niveau de la voix, à savoir qu'il y a des éléments phonétiques, mais qu'il y en a aussi beaucoup qui ne le sont pas, ceci étant d'autant plus frappant que, du point de vue de la structure, de la structure stricte de ce qu'il en est d'un langage, nulle langue ne se tient d'une façon plus pure que cette langue chinoise où chaque élément morphologique se réduit à un phonème. C'est donc bien là où ç’aurait été le plus simple, si l'on peut dire, que l'écriture ne soit que transcription de ce qui s'énonce en paroles, qu'il est frappant de voir que, tout au contraire, l'écriture, loin d'être transcription, est un autre système, un système auquel éventuellement s'accroche ce qui est découpé dans un autre support, celui de la voix" ("D'un Autre à l'autre", Lacan 1996: 316).

116 See his "Freud et la scène de l'écriture" (Derrida 1967: 318-328); cf. Birman (2007). 
Chinese sign. Such discourses incorporate a good modicum of the universal language movement's enchantment with Chinese writing during the seventeenth and early eighteenth century, and of the French orientalist discourse on Chinese as a lingua oculorum (Fourmont 1737: 26). ${ }^{117}$ Linguists have tended to avoid De la grammatologie like the plague; ${ }^{118}$ and trenchant remarks about Derrida's essentializing, ultimately ethnocentric use of non-European "traditions" by specialists in Asian studies are certainly not lacking. ${ }^{119}$ Some theoreticians of logographic writing, on the other hand, while bemoaning his often ill-informed take on the complexities of non-alphabetic scripts and his eurocentric view from "La pharmacie de Platon" (Derrida 1967), have nevertheless embraced the rejection of the Aristotelian "surrogationalist" view of writing, held to be articulated in Peri Hermeneias/De interpretatione I.I6a (Cooke \& Tredennick 1938 [20I4]: II4). ${ }^{120}$ While this passage in Aristotle is in fact open to conflicting interpretations ${ }^{121}$ which are not considered by Derrida, its standard reception ascribed to Aristotle the "phono-logocentristic" idea that writing, being merely a surrogate, is subordinate to spoken language. By consequence, writing largely disappeared from the realm of Saussurean and subsequent synchronic linguistics, which had explicitly set out to overcome "la tyrannie de la lettre" (Saussure i9ı6: 53).

Among the Tel Queliens, the sweeping rejection of the Aristotelian notion of the linguistic and graphical sign and, by consequence, of European logocentrism at large, probably had its strongest resonances in the work of Roland Barthes. This is evident form his Variations sur l'écriture, written in 1973, but published only in 2002 as part of the collected works (Barthes 2006 [1973]). Unfortunately, the introductory 2I historical "landmarks" (repères) listed by Barthes do not exactly inspire confidence in the author's reliability when tackling the subject. Thus, we read about Sumerian writing proper (écriture linéaire) being attested in Mesopotamia 35.000 years B.C. (off by one decimal place $^{122}$ ), of the appearance of Chinese writing "vers 1700 avant J.-C.” (off by some 350 years), about the unification of writing through a "cursive" version in the fourth century

117 For an excellent overview, see Maat (2004), cf. also Cohen (1954), Genette (1976: 64-7I), Singer (1989) and Tong (2010: 327-332). On Kircher's "pasigraphy" as a forerunner, cf. also McCracken (1948).

118 Only some of them for good reasons. For a sophisticated attempt to take Derrida's linguistic positions seriously, see Parret (1975).

119 See e.g. Spivak (1976: lxxxii, cited in Saussy 1993: 192 n. 9), Rey Chow (201I) and Halbfass (2007: I40).

120 For a discussion of this theme in comparison to medieval Chinese theories of writing, see Coulmas (2003: 2-5). For an explict linguistic critique of surrogationalism, see especially the work of Harris (1986, 200I); for cautious egyptological appraisals, cf. Kammerzell (1993), Galgano (2003) and Morenz (2008: II n. 36).

121 See, e.g., Maas (1986) and Stockhammer (20I4: 382-389).

122 It seems that Barthes either accidentally added one zero, or mixed up the date up with another of his landmarks, namely the appearance of "graphisme" from the end of the Moustérien (Barthes 2006 [1973]: 60-6I). 
B.C. in China (off by at least I80 years), ${ }^{123}$ or of the first appearance of the zero "dans la numérotation au XII siècle" (probably referring to Fibonacci and the transfer of the Hindu-Arabic numerical system to Europe, but otherwise off by almost 3000 years). ${ }^{124}$ The critique of the "triomphe de la Voyelle, donc de la Voie, donc de la Parole" (Barthes 2006 [1973]: 19I), brought about by the Greek "miracle" of the vowelled alphabet, ${ }^{125}$ obviously necessitates the resurrection of positing an "ideographic" (Egyptian, Chinese) or "consonantal" (Semitic) other, which has escaped the "préjugé transcriptionniste" (ibid.: 68) that has haunted Europe since Aristotle. In stark contrast to the critical, even revolutionary posture claimed in all political matters, Barthes is thus simply rehashing the same old missionary clichés about Chinese writing which have been used by the whole pedigree of European commentators on China since the seventeenth century. Anchoring not only the beginnings of Chinese writing in the realm of religion, ritual and divine communication (ibid.: 32), he even goes beyond the missionaries, when he denies its primary communicative function:

Chinese writing [...] was first aesthetic and/or ritual (used to address the gods) and then functional (used to communicate, to record); the communicative function, of which our linguists make a cream pie, is posterior, derivative, secondary; Chinese writing could thus not have been a decal picture of speech at first [...]. No, it is by no means obvious that writing serves to communicate. It is by an abuse of our ethnocentrism that we attribute purely practical functions of compatibility, communication, and recording to writing, and that we censor the symbolism that moves the written sign. ${ }^{126}$

Of course, he is not alone in this time-honored, ultimately Eurocentric perception, going back to Hegel and beyond. In the German-speaking world the idea that there exists a uniquely Chinese constellation of the "construction of language, the appearance of its writing, the net of concepts employed and the view of the world" (Sprachbau, Schriftbild, Begriffsnetz und Weltbild) is still encountered, for instance, with the Marxist philosopher Hans Heinz Holz (I927-20II) ${ }^{127}$ or with recent "critical" theories of writing, such as

123 Even if the date was intended to refer to Qin shi huang's so-called (Galambos 20II) unification of writing, rather than the appearance of xingshu 行書 "running script", usually associated with the Eastern Han calligrapher Liu Desheng 劉德昇 ( $f$. I47-I89).

124 Barthes (2006 [1973]: I3, I5, I19).

125 For a quasi-Pythagorean motivation of this alleged "miracle", see Friedrich Kittler's (I943-20II) now classic "Homeros und die Schrift" (Homeros and writing) and "Das Alphabet der Griechen: Zur Archäologie der Schrift" (The Greek Alphabet: On the archaeology of writing) in Kittler (20I4: 342-350, 35I-359).

126 "L'écriture chinoise [...] a d'abord été esthétique et/ou rituelle (servent à s'adresser aux dieux) et ensuite fonctionelle (servant à communiquer, à enregistrer); la fonction de communication, dont nos linguistes font une tarte à la crème, est postérieure, dérivée, sécondaire; l'écriture chinoise n'a donc pu être au départ un décalque de la parole [...]. Non, il ne va pas de soi que l'écriture serve à communiquer; c'est par un abus de notre ethnocentrisme que nous attribuons à l'écriture des fonctions purement pratiques de compatibilité, de communication, de l'enregistrement et que nous censurons le symbolisme qui meut le signe écrit" (Barthes 2006 [1973]: 30).

127 Most clearly in his China im Kulturvergleich (Holz 1994: 22-23, 34-38). 
Christoph Türcke's, who views Chinese characters as an instance of "visualized cultural history" (Türcke 2005: 79). "Undergirding the meaning of a word in a senso-emotional" fashion, Chinese characters are, according to Türcke, responsible for the "road grip of thought" (Bodenhaftung des Denkens), which relegates

[...] the conceptual abstractions time and again back to that, from which they have been abstracted. [...] Even in their most highly developed ideographic forms there still inheres so much of the history of images that they cannot cope with the capacity for abstraction of the words. Logographic writing was simply not made for the expression and conveyance of that kind of specific concept formation and train of thought which consolidated itself in occidental metaphysics and which animated the global triumph of Europe. ${ }^{128}$

Where Türcke invokes the "sensual grounding" (der sinnliche Boden) of the origins of logograms as a "moment of retardation, encouraging the stocktaking of oneself" (ein retardierendes, zur Selbstbesinnung aufforderndes Moment; ibid.: 78), it seems, at least to this author, that the leap towards other types of retardation is dangerously close. ${ }^{129}$

It is also quite depressing to see how a theory which holds the Chinese writing system to be the sole reservoir of intellectual activities to the detriment of an oral communication which has been reduced "à l'expression des banalités quotidennes" (Barthes 2006 [1973]: 50) even comes to influence the perception of everyday communist Chinese realities in Barthes' diary reflections on the 1974 Tel Quel expedition. Instead of looking through and beyond the repetitive slogans of Cultural Revolution propaganda, the "[e]ndlessly repeated doxa" (ibid.: I5), "vomitted out" by every worker, everything which Barthes dislikes about the daily life of revolutionary China stems from a view of language rooted in a deeply ethnocentric view of Chinese writing, "the only signifier" (ibid: II9). Like the ancient Chinese emperors, Mao - "in all the lounges, the wart on his chin" (ibid.: 35) - emerges as a successful "logothete" (ibid.: 134$)^{130}$, who has made his people pay "for the Revolution with everything I love: 'free' discourse exempt from all repetition, and immorality" (ibid.: 195). Assuming full control of the properties inherent in the Chinese language due to its reduction by the writing system, Mao has managed to reduce the discourse to

128 " [...] die begrifflichen Abstraktionen immer wieder auf das zurück, wovon sie abstrahiert sind. [...] Selbst ihren höchstentwickelten ideographischen Formen haftet noch so viel Bildvergangenheit an, daß sie mit der Abstraktionskapazität der Wörter nicht standhalten können. Zur Darstellung und Beförderung jener spezifischen Begriffsbildung und Gedankenführung etwa, die sich in der abendländischen Metaphysik verdichtete und den globalen Siegszug Europas beflügelte, ist die Logographie einfach nicht gemacht" (Türcke 2005: 79).

129 For a similar viewpoint, see Stetter (1997) to be read in conjunction with the criticism in Roetz (2005: 54-55; 2006: 1997). The retardation topic is clearly inherited from Hegel, who had already identified the Chinese Bilderschrift as incapable of representing abstractions. Cf. Saussy (2011: 39 and 205 n. I8).

130 It is curious how the doyen of German medieval studies, Arno Borst (1925-2007), long before the soixante-huitards, draws a very similar line running from the early Confucian "rectification of names" (zheng ming 正名) theory to mid-twentieth century Maoist Marxism and dialectics (Borst 1995, VI: 1767-8). 
[...] a combinatorial system of bricks, in which the very small degree of free play allows differences to emerge - doubtless requiring subtlety to decode. For this is not our code: this linguistics is not Saussurean. No idiolect. They probably have no discourse for love, for sociological information, etc. (Barthes 20I2: 27).

It is only logical, therefore, that in this post-Saussurean dreamland of, supposedly, non-arbitrary correspondences between words and referents, people in China "have to be taken literally. They are not interpretable" (ibid.: 32 , emphasis in the original). Notice that this is not just the kind of coquettish semiotic pribble-prabble, which prompted a sinologist such as Simon Leys to speak of "un incurable et lugubre charlatan" in the parallel case of Lacan. ${ }^{131}$ For one can see just how serious Barthes' belief in the alleged difference is, for instance when the childishness topic of German idealism resurfaces and he starts to doubt "and what if all this country were simply: completely naïve?" (ibid.: 64). Such a naiveté would obviously undermine all prospects for a future revolution in France "where the way language works is different, specific" (ibid.: I4I).

\section{Envoi}

Theories on early Sino-Western long-distance trade and remote cultural contacts continue to fascinate sinologists, historians and "civil society" media alike. Whether we read about Chinese silk in a Middle Kingdom Pharaonic tomb (Lubec et al. 1993; but cf. Good 1995), the terracotta army sculptures as influenced by Hellenistic aesthetics (Nickel 2013), or the practices of fire cremation, column capital decoration and hashish consumption in China as Iranian imports (Jao \& Vandermeersch 2006; Yi 20I3: 9; Svobodová 2018), wide public attention and acrimonious ridicule from the establishments of "national learning” (guoxue 國學) in China and of sinology (hanxue 漢學) abroad are usually guaranteed. No doubt, not only a few of the I40 odd plants, animals, foodstuffs, minerals, metals, implements and other items featuring in Yu Taishan's (2002) convenient list of “exotic" products from the 'Western territories' ( $x i y u$ 西域) known from Han and Early Medieval sources, will eventually turn out to have a much older prehistory than commonly assumed, but we will need far more archaeological data to prove this. Early Sino-Greek textual parallels in proverbs (Giles 1923), in Eurasian travelling stories about bizarre animals (Franke 1963) or in the construction of paradoxes and other highly specific "narratemes" (Brooks 1999) are usually more difficult to date and assess, as are ideas about Indian backgrounds in early Daoist texts (Mair 1990) or archaic Chu 楚 literary forms (Rao 1983). And "long-range" linguistic theories genetically linking Old Chinese to non-Tibeto-Burman families ${ }^{132}$ or, for that matter, Tibeto-Burman to Sumerian, ${ }^{133}$ will be even harder to sell. Obviously, a lot of the scepticism such proposals arouse has to do with the political motivations, sensibilities and overtones they have. Palpable during the nation-building times of Terrien La Couperie and his "Western origin theory” (xilai shuo 西來說) followers in China (Matten 2009; Fan Fa-ti 2008), or in the

131 E-mail of 24 January 20I4, cited in Paquet (2016: 216 n.).

132 For a short characterization and bibliography of these hypotheses, see Behr (2013: 394-407).

133 Cf. Braun (2000; 2004). 
case of the criticism of Johann Gunnar Andersson's (I874-1960) ideas about the Western provenance of Yangshao 仰韶 and other Neolithic ceramics along the "Eastern silkroad highway", ${ }^{134}$ they are once again "in the air" in the wake of the "One-Belt-One-Road" initiative of the People's Republic today. Archaeology in China, like in so many other contexts in Europe and elsewhere, was not only a handmaid of historiography (Chang I98I; von Falkenhausen 1993), but a myrmidon of politics as well since its Republican period beginnings onwards. ${ }^{135}$

Michael Lackner has recently shown how "Western origin" theories in the history of science, religions and historiography in Late Qing and Republican China have inevitably produced layers, often cycles of perenially reappearing counternarratives (Lackner 2008). The two most commonly encountered figures of argumentation in such disputes include the diachronic incorporation and containment of the foreign into the own and the relativistic positing of its inscrutability via recourse to "special Chinese characteristics” (Zhongguo tese 中國特色). The “reclaiming” of Yangshao pottery by the Chinese autochthony model would be a good example of the former type of argument, the anti-universalist movement of "Chinese cultural linguistics" (Zhonguo wenhua yuyanxue 中國文化語言學) of the 1980-90s (Höhenrieder 20I5) a typical case of the latter. More often than not, such reactions have been automatized as a reflex, especially where they accompany anti- and postcolonial processes of self-reassurance or nation-building. ${ }^{136}$ Thus, when the Soviet sinologist Leonid S. Vasil'ev (1930-2016) tried to revisit foreign influences in the origins of the Chinese civilization, state and thought in three well-documented tomes (Vasil'ev 1976; 1983a, b), he was immediately shouted down by a number of scholars in China (e.g. Yang Jianfang 1977; Shao Wangping \& Mo Runxian 1989). Reading the long-winding justifications of why a discussion of Western elements in the ethnogenesis of the Qin should be possible "as well” or "again” in three recent excellent articles on the subject reviewing the archaeological and textual evidence (Yong Jichun 20II; Shi Dangshe 2015; Liang Yun 2017) one can sense how difficult it is for younger authors to approach the important question even halfway unburdened by political afterthoughts.

A third counternarrative option mentioned by Lackner consists in the relegation of such sensitive geohistorical debates to a neutral "universalist" territory, beyond the confines of parochialist nation state claims. This figure of thought has become much rarer in recent years, it seems, although it would no doubt help to decenter an all-too-familiar directionality. Goods, institutions and ideas of interest to modern scholarship still travel predominantly ex occidente along the mental, continuously reinvented silk roads. ${ }^{137}$ It is

134 For conflicting assessments of Andersson's role and loyalties, see Chen Xingcan \& Ma Sizhong (2005), Johansson (2012: 45-67; 2016), Zhou Shucan (2016) and Fiskesjö (2017).

135 Telling case studies of that precarious relationship include Sautman (200I), Kyong-McClain (20I0) and Leibold (20II).

136 Witness, for instance, the apparent struggle to reconcile such origin theories with the idea of a shared Sino-Tibetan descent in the Late Qing period (Zhaluo 2013).

137 For a conceptual history of the term, see Chin (2013); for a sketch of its prehistory, see Di Cosmo (2014). 
hardly known in "the" West, for instance, that Gottfried Wilhelm Leibniz (I646-I7I6) conceived the establishment of the "Sozietät der Wissenschaften", later the Prussian Academy of Sciences, along the lines of the Hanlin 翰林 academy of Chinese antiquity, with the explicit aim of "an exchange between the cultures of Europe and China" (Schickel 1976 [1968]: 157); or that, more generally, European Enlightenment secularism is deeply indebted to the reception of Confucian thought on many levels (Weststijn 2007; Roetz 2013; Lu Mingjun 2015). ${ }^{138}$

Returning to the realm of language, then, we can observe that von der Gabelentz, contrary to the prevailing nineteenth century idea of Chinese being stuck in a primordial plainness, benumbed, as it were, in a Hegelian stasis eventually leading into "Oriental despotism", elevates Chinese along with the structurally comparable English to the spearhead of linguistic modernity. As if seemlessly continuing the Enlightenment philosophers' enchantment with Chinese thought and institutions, he writes:

If Chinese and English are the most modern languages in the world, we may say that their constitution may be likened to a democratic bureaucracy along the lines of the Chinese body politic. In accordance with talent, each individual may acquire power and dignity there, but only the echelon, the respective position of the individual within the whole, confers power and dignity upon him. ${ }^{139}$

Having changed the usual diachronic isolation $\rightarrow$ inflection directionality and bridged the geographical East/primitive $\rightarrow$ West/progressive divide, he decentralizes the comparison even further, when he carefully avoids falling into the trap of constructing the parallel unloading of the "ballast of morphology" (Ballast der Formenlehre; Gabelentz 2016 [I89I]: 455) in the isolating typologies of Chinese and English as some kind of elective East-West Culturvolk affinity: "The Bantu distinguish their parts of speech at least as strictly as the old Indoeuropeans theirs" (ibid.: 464). The reason for these parallels, he holds, casually introducing a term still widely used in linguistics today, are rather to be sought in the entanglements of language contact (Contact der Sprachen; ibid.: 416):

Already in its most ancient monuments the Chinese language creates the impression of an abrasive wear in comparison to its less learned genealogical relatives, from which one can infer important mixtures of the populace in prehistory. Quite a few mixtures of this type have been experienced by the Chinese nation during historic times, and they usually took place in a peaceful manner, at least in such a way that those newly received soon merged into Chineseness. Whether it was due to the peculiarities of Chinese traditions of behav-

138 See also Csikszentmihalyi (2014) on the "transmogrifications" of Daoist idieas about wuwe $i$ 無為 (inactivity) into eighteenth century European discourses on laissez-faire or on the afterlives of the Mengzian idea of universal moral dispositions into Auguste Comte's (I798-I857) generalized vivre pour l'autrui ethics.

139 "Sind Chinesisch und Englisch die modernsten Sprachen der Welt, so darf man sagen, ihre Verfassung sei eine demokratische Bureaukratie nach Art des chinesischen Staatswesens. Da kann es jedes Individuum je nach seiner Begabung zu jeglicher Macht und Würde bringen, aber nur der Rang, die jeweilige Stellung des Einzelnen im Ganzen verleiht Macht und Würde" (Gabelentz 2016 [1891]: 455). 
ior or to the conducive talents of the aboriginal inhabitants, there have never been helots in the Middle Kingdom. Where nations do not segregate along the boundaries of rank, hereditary aristocracy is deprived of its basis. And, conversely, [...] where different nations converge in one statehood linkage, they thereby express a certain democratic inclination. In that regard, the same forces may have participated in the creation of the Chinese states and of the Chinese language. ${ }^{140}$

It is heartening to see, especially in view of a European history blaming the Chinese language for the lack of many political and philosophical developments ${ }^{141}$ and in view of the contemporary politics of the People's Republic, that one could argue against all prevailing clichés at the end of the nineteenth century that the structure of the Chinese language reflected ancient democratic tendencies. This may be a kind of reverse orientalism, of course, but at least it shows that monosyllabism has no evidential value in this discourse, as Gabelentz noticed already at the Fourth International Congress of Orientalists in Venice in I878: "Le monosyllabisme, nous l'avons vu, ne prouve rien" (Gabelentz I88I: 287).

\section{Bibliography}

Adelung, Johann C., with supplements by Wilhelm von Humboldt, Friedrich von Adelung \& Johann Severin Vater (1806-I7). Mithridates, oder Allgemeine Sprachenkunde, mit dem Vater Unser als Sprachprobe in bey nahe fünf hundert Sprachen und Mundarten. Berlin: Vossische Buchhandlung.

Allen, Don C. (1960). "The Predecessors of Champollion." In: Proceedings of the American Philosophical Society 104.5: 527-547.

[Anonymus] (1773). Lettre de Pekin sur le génie de la langue chinoise, et la nature de leur écriture symbolique, comparée avec celle des anciens Égyptiens; en réponse à celle de la Société Royale des Science de Londres, sur le même sujet ... Par un Père de la Compagnie de Jesus, Missionaire à Pekin. Bruxelles: J.L. de Boubers.

Aristotle (2014 [1938]). Categories. On Interpretation. Prior Analytics. H. P. Cooke \& Hugh Tredennick (eds. \& transl.). Cambridge/Mass.: Harvard University Press.

140 "Schon in ihren ältesten Denkmälern macht die chinesische Sprache, verglichen mit ihren minder gebildeten Stammverwandten, den Eindruck einer Verschliffenheit, die auf bedeutende vorgeschichtliche Mischungen des Volkes schliessen lässt. Solcher Mischungen hat die chinesische Nation in geschichtlicher Zeit noch manche erlebt, und sie vollzogen sich in der Regel friedlich, mindestens so, dass die Neuaufgenommenen bald im Chinesenthume aufgingen. Lag es in der Eigenthümlichkeit der chinesischen Gesittung, lag es in der günstigen Begabung der Ureinwohner, Heloten hat das Mittelreich nie gehabt. Wo aber die Nationen sich nicht ständeweise gegeneinander absondern, da ist der Erbaristokratie der Boden entzogen. Und umgekehrt [...], - wo verschiedene Nationen sich als Gleichberechtigte in ein Staatsthum zusammenschicken, da bekunden sie eben dadurch eine gewisse demokratische Neigung. Insoweit mögen dieselben Kräfte an der Bildung des chinesischen Staates und der chinesischen Sprache Antheil gehabt haben" (Gabelentz 2016 [I89I]: 4I6). Similarly, again, Terrien de Lacouperie: "Parmi ces causes, l'éxtension géographique, et le mélange avec les races non chinoises, qui ont caractérisé de plus en plus le développement des Chinois, ont joué certainement un rôle dominant dans cette alteration progressive" (Terrien de Lacouperie I889: 258).

141 See Roetz (1995) for an insightful critique. 
Arlotto, Anthony T. (1968). “On Defining 'Monosyllabism.” In: Journal of the American Oriental Society 88.3: 521-522.

Babinger, Franz (1915). Gottlieb Siegfried Bayer (I694-I738). Ein Beitrag zur Geschichte der morgenländischen Studien im I8. Jahrhundert. München: Schön.

Backhaus, Wilhelm (1976). "Der Hellenen-Barbaren-Gegensatz und die Hippokratische Schrift

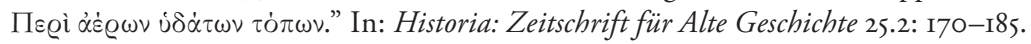

Ball, Charles J. (1913). Chinese and Sumerian. Oxford: Oxford University Press.

Barthes, Roland (2006 [1973]). Variations sur l'écriture: französisch-deutsch. Hans-Horst Henschen (ed. \& transl.). Mainz: Dieterich.

Barthes, Roland (20I2). Travels in China. Anne Herschberg Pierrot (ed. \& annot.); Andrew Brown (transl.). Cambridge: Polity Press.

Bartschat, Brigitte (1996). "Sprachwissenschaft und Sprachforschung bei Georg von der Gabelentz.” In: Eugenio Coseriu (ed.): Sprachwissenschaftsgeschichte und Sprachforschung OstWest Kolloquium, Berlin 1995. Tübingen: G. Narr: 87-96.

Baxter, William H. \& Sagart, Laurent (20I4). Old Chinese: A New Reconstruction. Oxford: Oxford University Press.

Beekes, Robert P.E. \& Beek, Lucien van (2010). Etymological Dictionary of Greek. Leiden \& Boston: E.J. Brill.

Behr, Wolfgang (2000). "Dissensor docet - Anmerkungen zu Wei Jingshengs kulturvergleichenden Essays.” In: Christina Neder, Heiner Roetz \& Ines S. Schilling (eds.): Gedenkschrift Helmut Martin. Wiesbaden: O. Harrassowitz: 397-416.

Behr, Wolfgang (2001/o2). Review of Jan Ulenbrook, Zum Alteurasischen. Eine Sprachvergleichung. Bettendorf: Kult-Ur-Institut für interdisziplinäre Kulturforschung, 1998. In: Oriens 36: 356-361.

Behr, Wolfgang (2004). “'To Translate' is 'to Exchange’ 譯者易也 - Linguistic Diversity and the Terms for Translation in Ancient China.” In: Natascha Vittinghoff \& Michael Lackner (eds.): Mapping Meanings: The Field of New Learning in Late Qing China. Leiden: E.J. Brill: 173-209.

Behr, Wolfgang (2009). "In the Interstices of Representation: Ludic Writing and the Locus of Polysemy in the Chinese Sign." In: Alex de Voogt \& Irving L. Finkel (eds.): The Idea of Writing: Play and Complexity. Leiden: E.J. Brill: 28I-3I4.

Behr, Wolfgang (2010). "Role of Language in Chinese Constructions of Ethnic Identity." In: Journal of Chinese Philosophy 37.4: 567-587.

Behr, Wolfgang (2013). "Genealogie, Phonologie und Morphologie des Antikchinesischen.” In: Robert H. Gassmann \& Wolfgang Behr (eds.): Grammatik des Antikchinesischen: Begleitband zu Antikchinesisch - Ein Lehrbuch in zwei Teilen. Bern: Peter Lang: 399-464.

Behr, Wolfgang (20I5a). "Kingsmill's Shijing 'Translations' into Sanskrit and the Idea of 'Congenial Languages' at the End of the igth Century.” In: Lawrence Wang-chi Wong \& Bernhard Führer (eds.): Sinologists as Translators in the Seventeenth to Nineteenth Centuries. Hong Kong: The Chinese University Press: 307-354.

Behr, Wolfgang (2015b). “G. Sampson, 'A Chinese Phonological Enigma:' Four Comments.” In: Journal of Chinese Linguistics 43.2: 719-732.

Behr, Wolfgang \& Führer, Bernhard (2005). "Einführende Notizen zum Lesen mit besonderer Berücksichtigung der Frühzeit." In: Bernhard Führer (ed.): Aspekte des Lesens in China in Vergangenheit und Gegenwart. Bochum: Projekt Verlag: I-44.

Behr, Wolfgang \& Söderblom-Saarela, Mårten (forthcoming). “'Radicals,' and Why They Are Called That." In: Rint P.E. Sybesma et al. (eds.): Encyclopedia of Chinese Language and Linguistics, Leiden: E.J. Brill, online edition 2018. 
Beyer, Theophilus (1730). Museum Sinicum. In quo Sinicae Linguae et Litteraturae ratio explictur, $t$. I, Praefationem historicam ... comprehendit. St. Petersburg: Imperial Academy Press.

Bickel, Balthasar (20I4). "Lingustic Diversity and Universals." In: Nick J. Enfield, Paul Kockelman \& Jack Sidnell (eds.): The Cambridge Handbook of Linguistic Anthropology. Cambridge: Cambridge University Press: IO2-I27.

Binsbergen, Wim M. J. van (2009/2010). "Yi Jing and West Asia: A Partial Vindication of Terrien de Lacouperie." In: Quest. An African Journal of Philosophy I-2: I-398, at 215-253.

Birman, Joël (2007). "Écriture et psychanalyse ı: Derrida, lecteur de Freud." In: Figures de la psychanalyse I5.I: 20I-2I8.

Bold, John (198I). "Composite Capitals and the Chinese Language." In: Oxford Art Journal 4.I: 9-17.

Boltz, William (2000). Monosyllabicity and the Origin of the Chinese Script. Berlin: Max-PlanckInstitut für Wissenschaftsgeschichte. (MPG Preprints I43).

Boltz, William G. (20I7). “liù shū 六書 (Six Scripts)." In: Rint P.E. Sybesma et al. (eds.): Encyclopedia of Chinese Language and Linguistics. Vol. 2 (De-Med): 616-624.

Borst, Arno (1995 [1957-1963]). Der Turmbau von Babel: Geschichte der Meinungen über Ursprung und Vielfalt der Sprachen und Völker, 4 pts. Stuttgart: Hiersemann, repr. in 6 vols., München: dtv.

Bourseiller, Christophe (1996). Les maoïstes: la folle histoire des gardes rouges français. Paris: Plon.

Bopp, Franz (1833-1852). Vergleichende Grammatik des Sanskrit, Zend, Griechischen, Lateinischen, Litauischen, Gotischen und Deutschen. Berlin: Druckerei der Königl. Akademie der Wissenschaften, bei Ferdinand Dümmler.

Braun, Jan (200I). Sumerian and Tibeto-Burman. Warszawa: Agade.

Braun, Jan (2004). Sumerian and Tibeto-Burman: Additional Studies. Warszawa: Agade.

Brooks, E. Bruce (1999). Alexandrian Motifs in Chinese Texts. Philadelphia: Department of East Asian Languages and Civilizations, University of Pennsylvania. (Sino-Platonic Papers 96).

Buckley, Eugene (2008). "Monosyllabicity and the Origins of Syllabaries." Paper presented at the Annual Meeting of the Linguistic Society of America, Chicago, 3-6 January 2008; http:// www.ling.upenn.edu/ - gene/papers/monosyllabicity.pdf (last visited 21.I2.2017).

Burnouf, Eugène (I829-1843). Extrait d'un commentaire et d'une traduction nouvelle du Vendidad Sadé, l'un des livres de Zoroastre: avec un commentaire, une traduction nouvelle et un mémoire sur la langue Zende considérée dans ses rapports avec le Sanscrit et les anciens idiômes de l'Europe. Paris: s.n.

Campbell, Lyle (20I7). "The History of Linguistics: Approaches to Linguistics." In: Mark Aronoff \& Janie Rees-Miller (eds.): The Handbook of Linguistics. 2nd edition. Hoboken: WileyBlackwell: 97-II8.

Cao Jinyan 曹錦炎 (1999). Niao chong shu tongkao 鳥蟲書通考. Shanghai: Shanghai Shuhua Chubanshe 上海書畫出版社.

Carlyle, Edward I. (I898). “Terrien De La Couperie, Albert Étienne Jean Baptiste.” In: Sidney Lee (ed.): Dictionary of National Biography. Vol. 56. London: Smith, Elder \& Co.

Chaitin, Gilbert. D. (2009). Rhetoric and Culture in Lacan. Cambridge: Cambridge University Press.

Champollion, Jean-François (1824/28). Précis du systèm hiéroglyphique des anciens Égyptiens, ou, Recherches sur les élémens premier de cette écriture sacrée, sur leurs diverses combinaisons, et sur les rapports de ce système avec les autres méthodes graphiques égyptiennes. Paris: Treuttel/s.n.

Chang, K. C. (198I). "Archaeology and Chinese Historiography." In: World Archaeology 13.2: 156-169. 
Chao Fulin 昆福林 (1999). "Lun qian-yigu shidai - Wusi wenhua yundong yu xueshu fangfa biange 論前疑古時代一一五四新文化運動與學術方法的變革.” In: Beijing Shifan Daxue Xuebao 北京師範大學學報 152.2 : 58-65.

Ch'en, Shou-yi 陳受頣 (1935-36). "John Webb: A Forgotten Page in the Early History of Sinology in Europe." In: The Chinese Social and Political Science Review 9: 295-30.

Chen Xingcan 陳星燦 \& Ma Sizhong 馬思中 (2005). “Hu Shi yu Antesheng - jiantan Hu Shi dui 20 shiji qianbanye Zhongguo kaoguxe de kanfa 胡適與安特生一一兼談胡適對20世紀 前半葉中國考古學的看法.” In: Kaogu 考古 I: 76-87.

Chen, Yongsheng (2016). "The Prototypical Determinatives in Egyptian and Chinese Writing." In: SCRIPTA - The Journal of the Hunmin Jeongeum Society 8: IOI-I26.

Chevalier, Jean-Claude (1979). "Un obstacle épistémologique en I825: le chinois à Paris." In: Romantisme 25-26 (special issue "Conscience de la langue"): IO7-II6.

Chin, Tamara (2013). “The Invention of the Silk Road, I877." In: Critical Inquiry 40.I: 194-219.

Chow, Rey (200I). "How (the) Inscrutable Chinese Led to Globalized Theory." In: Proceedings of the Modern Language Association II6.I: 69-74.

Cohen, Jonathan (1954). "On the Project of a Universal Character." In: Mind, n.d., 63.5: 49-63.

Collani, Claudia von (198I). Die Figuristen in der Chinamission. Frankfurt am Main etc.: P. Lang.

Collani, Claudia von (1985). P. Joachim Bouvet S.J: sein Leben und sein Werk. Nettetal: Steyler.

Collani, Claudia von (1998). "Amiot, Jean-Joseph-Marie.” In: Friedrich Wilhelm Bautz (ed.): Biographisch-Bibliographisches Kirchenlexikon. Vol. I4. Herzberg: Bautz: Sp. 697-700.

Coulmas, Florian (2003). Writing Systems. An Introduction to their Linguistic Analysis. Cambridge: Cambridge University Press.

Cordier, Henri (1920). Histoire générale de la Chine et de ses relations avec les pays étrangers depuis les temps les plus anciens jusqu'à la chute de la dynastie manchoue. Vol. I: Depuis les temps les plus anciens jusqu'à la chute de la dynastie T’ang (907 après J.-C.). Paris: Librairie Paul Geuthner.

Craik, Elizabeth M. (2015). The Hippocratic Corpus. Content and Context. London \& New York: Routledge.

Csikszentmihalyi, Mark (2014). "Finding Altruism in China." Unpublished paper, UC Berkeley. http://www.academia.edu/62I4406/ (last visited 22.06.2016).

Curran, Brian A. (1998-1999).“'De sacrorum litterarum Aegyptiarum interpretatione.' Reticence and Hubris in Hieroglyphic Studies of the Renaissance: Pierio Valeriano and Annius of Viterbo." In: Memoirs of the American Academy of Rome 43/44: 139-82.

Daniels, Peter (1992). "The Syllabic Origin of Writing and the Segmental Origin of the Alphabet." In: Pamela Downing, Susan Lima \& Michael Noonan (eds.): The Linguistics of Literacy. Amsterdam and Philadelphia: John Benjamins: 83-IIo.

David, Madeleine (1965). Le débat sur les écritures et l'hiéroglyphe aux XVIIe et XVIIIe siècles et l'application de la notion de déchiffrement aux écritures mortes. Paris: S.E.V.P.E.N.

Demiéville, Paul (1967). "Les premiers contacts philosophiques entre la Chine et l'Europe." In: Diogène 58: 8I-IIO.

Derrida, Jacques (1967). De la grammatologie. Paris: Les Éditions de Minuit.

Derrida, Jacques (1968). “La pharmacie de Platon.” In: Tel Quel 32/33: 257-403.

DiCosmo, Nicola (20I4). "A Note on the Formation of the 'Silk Road' as Long-Distance Exchange Network.” In: Mehmet Bulut (ed.): ReSILKROAD. Istanbul: Istanbul Sabahattin Zaim University (IZU) Publications: 17-26.

Di Sebastiano, Lucrezia (2013/I4). Storia Culturale della Lingua Esperanto in Cina. Tesi di Laurea. Università Ca'Foscari, Venezia. http://dspace.unive.it/bitstream/handle/I0579/5456/844605-II7683I.pdf?sequence=2 (last visited I2.02.2018). 
Doerfer, Gerhard (1963-75). Türkische und mongolische Elemente im Neupersischen unter besonderer Berücksichtigung älterer neupersischer Geschichtsquellen, von allem der Mongolen- und Timuridenzeit. 4 Vols. Wiesbaden: Franz Steiner.

Drocourt, Zhitang (2013). "Abel-Rémusat et sa pensée linguistique sur le chinois." In: Actes en ligne du Ve Congrès de la Société des études romantiques et dix-neuvièmistes: Le XIXe siècle et ses langues. Lyon. http://etudes-romantiques.ish-lyon.cnrs.fr/wa_files/Langues-Drocourt.pdf (last visited 22.12.2017).

Dryer, Matthew S. \& Haspelmath, Martin (2013 eds.). The World Atlas of Language Structures Online. Leipzig: Max Planck Institute for Evolutionary Anthropology. http://wals.info (last visited 04.06.2018).

Dubs, Homer (1952). "On the Supposed Monosyllabic Myth." In: Journal of the American Oriental Society 72.2: 82-83.

Durt, Hubert (1980). "In Memoriam Paul Demiéville (I895-1979)." In: Numen 27.I: I-8.

Dybo, Anna (2007). Lingvističeskie kontakty rannix tjurkov. Leksičeskij fond. Pratjurskij period. Moskva: Vostočnaja literature.

Edmondson, Jerrold A. (1999). "Steinthal and the History of Chinese Linguistics." In: J. Leopold (ed.): The Prix Volney: Contributions to Comparative Indo-European, African and Chinese Linguistics. Max Müller and Steinthal. Vol. 3. Dordrecht: Kluwer Academic Publishers: 38I-498.

Falkenhausen, Lothar von (1993). "On the Historiographical Orientation of Chinese Archaeology." In: Antiquity 67: 839-849.

Fan, Fa-ti (2008). "How Did the Chinese Become Native? Science and the Search for National Origins in the May Fourth Era." In: Kai-wing Chow et al. (eds.): Beyond the May Fourth Paradigm: In Search of Chinese Modernity. Plymouth: Lexington Books: 183-208.

Fang, Weigui (1992). Das Chinabild in der deutschen Literatur, I871-1933: ein Beitrag zur komparatistischen Imagologie. Frankfurt am Main: P. Lang.

Felsch, Philipp (2015). Der lange Sommer der Theorie. Geschichte einer Revolte 1960-1990. München: C. H. Beck.

Findlen, Paula (2003 ed.). Athanasius Kircher: The Last Man who Knew Everything. New York: Routledge.

Fiskesjö, Magnus (2017). "Chinese Autochthony and the Eurasian Context: Archaeology, Mythmaking and Johann Gunnar Andersson's 'Western Origins'.” In: Kathryn O. Weber et al. (eds.): Fitful Histories and Unruly Politics. Rethinking Temporality and Community in Eurasian Archaology. Leiden: E.J. Brill: 303-320.

Flecher, Guy (n.d.). "Lacan et les religions de Chine," 26 pp. http://www.lacanchine.com/FG2o. html (last visited 2I.I2.20I7).

Fourmont, Stephanus [=Étienne] (1737). Meditationes Sinicae, in quibus $I^{0}$. Consideratur Lingua Philosophice atque Universalis Natura qualis esse, aut debeat, aut possit, $2^{\circ}$. Lingua Sinarum Mandarinicam ... Lutetiae Parisiorum: Musier, Jombert, Briasson \& Bullot.

Franke, Herbert (1963). "Indogermanische Mythenparallelen zu einem chinesischen Text der Han-Zeit." In: Hugo Kuhn \& Kurt Schier (eds.): Märchen, Mythos, Dichtung. Festschrift zum 90. Geburtstag Friedrich von der Leyens am I9. August 1963. München: C. H. Beck: 243-249.

Freud, Siegmund (1982 [1900]). Die Traumdeutung. In: Alexander MitscherIich, Angela Richards \& James Strachey (eds.): Studienausgabe. Vol. 2. Frankfurt am Main: Fischer.

Freud, Siegmund (1913). The Interpretation of Dreams. A.A. Brill (transl.). New York: MacMillan. Friedrich, Michael (2004). "Literary Chinese, Georg von der Gabelentz, and Synchronic Linguistics." In: Ken'ichi Takashima \& Jiang Shaoyu (eds.): Meaning and Form: Essays in PreModern Chinese Grammar. München: Lincom Europa: 43-55. 
Gabelentz, Hans Georg Conon von der (I88I). "Sur la possibilité de prouver l'existence d'une affinité généalogique entre les langues dites indochinoises." In: Atti del 4. Congresso Internazionale degli Orientalisti 1878 tenuto in Firenze nel settembre 1878. Vol. 2. Firenze: Coit tipi dei successori Le Monnier: 283-295.

Gabelentz, Hans Georg Conon von der (2016 [1891]). Die Sprachwissenschaft, ihre Aufgaben, Methoden und bisherigen Ergebnisse. Manfred Ringmacher \& James McElvenny (eds.). Vol. I. Berlin: Language Science Press.

Galgano, Beatrice (2003). "Derrida's De la Grammatologie and Hieroglyphic Writing." In: Lucia Morra \& Carla Bazzanella (eds.). Philosophers and Hieroglyphs. Torino: Rosenberg \& Sellier: I40-158.

Galambos, Imre (2004). “The Myth of the Qin Unification of Writing in Han Sources.” In: Acta Orientalia Academiae Scientiarum Hungaricae 57.2: 18I-203.

Gasde, Horst-Dieter (1993). Sinologische Traditionen im Spiegel neuer Forschungen. Ralf Moritz, Mayke Wagner \& Wilmar Mögling (eds.). Leipzig: Leipziger Universitätsverlag: I37-I46.

Gehrig, Sebastian; Mittler, Barbara \& Felix Wemheuer (eds.) (2008). Kulturrevolution als Vorbild? Maoismen im deutschsprachigen Raum. Frankfurt, New York etc.: Peter Lang.

Genette, Gérard (1976). Mimologiques.Voyages en Cratylie. Paris: Seuil.

Georg, Stefan (200I). "Türkisch/Mongolisch tengri 'Himmel, Gott' und seine Herkunft." In: Studia Etymologica Cracoviensia 6: 83-100.

Gernet, Jacques (I979). "Paul Demiéville (I894-1979)." In: T’oung Pao (2nd ser.) 65.I-3: I-9.

Giles, Lionel (1923). "Two Parallel Anecdotes in Greek and Chinese." In: Bulletin of the School of Oriental Studies 2.4: 609-6II.

Girardot, Norman J. (2002). The Victorian Translation of China: James Legge's Oriental Pilgrimage. Berkeley: University of California Press.

Gobineau, Arthur (1967 [1853-1855]). Essai sur l'inégalité des races humaines. Hubert Juin (ed.). Vol. I-4. Paris: Éditions Pierre Belfond.

Goldwasser, Orly (20I0). "How the Alphabet was Born from Hieroglyphs." In: Biblical Archaeology Review 36.2: 40-53.

Gong, Yushu 拱玉書 (1998). “Xiexing wenzi yu ‘liu shu’楔形文字與「六書」.” In: Zhang Dianying 張殿英 et al. (eds.): Dongfang yanjiu: jinian bainian xiaoqing lunwenji 東方研究: 紀念百年校慶論文集. Beijing: Lantian: 25-50.

Good, Irene (1995). "On the Question of Silk in Pre-Han Eurasia." In: Antiquity 69: 959-968.

Guan Xihua 管錫華 (2002). Zhongguo gudao biaodian fuhao fazhanshi 中國古代標點符號發展 史. Chengdu: Ba-Shu Shuhe 巴蜀書社.

Guignes, Joseph de (1760). Mémoire dans lequel on prouve que les Chinois, sont une colonie égyptienne, lù dans l'Assemblée royale des Inscriptions \& Belles-Lettres, le 14. Novembre 1758. Avec un précis du mémoire de M. l'Abbé Barthélemy, sur les Lettres phéniciennes, lû dans l'Assemblée publique de la même Académie, le I2. avril I758. Paris: Desaint \& Saillant.

Guy, Basil (1963). The French Image of China before and after Voltaire. Genève: Institut et Musée Voltaire.

Hal, Toon van (2010). Moedertalen en taalmoeders. Het vroegmoderne taalvergelijkende onderzoek in de Lage Landen. Brussels: Paleis der Academiën.

Halbfass, Wilhelm (1990). India and Europe. An Essay in Philosophical Understanding. New Delhi: Motilal Banarsidass.

Halbfass, Wilhelm (2007). "Research and Reflection: Responses to my Respondents." In: Eli Franco \& Karin Preisendanz (eds.): Beyond Orientalism: the Work of Wilhelm Halbfass and its Impact on Indian and Cross-Cultural Studies. Delhi: Motilal Banarsidass Publishers: 140-159. 
Hamann, Byron E. (2008). "How Maya Hieroglyphs Got their Name: Egypt, Mexico, and China in Western Grammatology since the Fifteenth Century." In: Proceedings of the American Philosophical Society I52.I: I-68.

Hannas, William C. (2003). The Writing on the Wall: How Asian Orthography Curbs Creativity. Philadelphia: University of Pennsylvania Press.

Harbsmeier, Christoph (1979) (ed. \& transl.). Wilhelm von Humboldt, Brief an M. Abel-Rémusat über die Natur grammatischer Formen im allgemeinen und über den Geist der chinesischen Sprache im besonderen. Stuttgart-Bad Cannstatt: Frommann-Holzboog.

Harbsmeier, Christoph (1995). "John Webb and the Early History of the Study of the Classical Chinese Language in the West." In: Ming Wilson \& John Cayley (eds.): Europe Studies China. Papers from an International Conference on the History of European Sinology. Taipei: Han-Shan Tang Books 6, The Chiang Ching-kuo Foundation for International Scholarly Exchange: 297-338.

Harris, Roy (1986). The Origin of Writing. LaSalle, Ill.: Open Court.

Harris, Roy (200I). Rethinking Writing. London etc.: Continuum.

Hartman, Janine (1998). "Ideograms and Hieroglyphs: The Egypto-Chinese Origins Controversy in the Enlightenment." In: Dalhousie French Studies 43: IOI-II8.

Hayot, Eric Robert J. (1999). Chinese Dreams: Pound, Brecht, 'Tel Quel.' Unpublished Ph.D Diss. The University of Wisconsin-Milwaukee.

He Bingsong 何炳松 (1929). “Zhonghua minzu qiyuan zhi jingshenhua 中華民族起源之精神 化.” In: Dongfang Zazhi 東方雜誌 26.2: 79-97.

Hermans, Michel (2005). "Joseph-Marie Amiot, une figure de la rencontre de 'l'autre' au temps des Lumières." In: Yves Lenoir \& Nicolas Standaert (eds.), avec la collaboration de Michel Brix, Michel Hermans \& Brigitte van Wymeersch: Les Danses rituelles chinoises d'après JosephMarie Amiot. Aux sources de l'ethnochoréographie. Namur: Éditions Lessius \& Presses universitaires de Namur: II-78.

Hernández, Javier A. \& Zhao, Iris (2017). “Trump’s Visit to China Provides a Propaganda Bonanza." In: The New York Times (Io November). https://www.nytimes.com/2017/II/Io/ world/asia/china-trump-visit-propaganda.html (last visited 28.02.20I8).

Hervouet, Yves (198I). "Paul Demiéville et l'École française d'Extrême-Orient." In: Bulletin de l'École française d'Extrême-Orient 69: I-29.

Hirst, Cecily (2000/oI). "The Origin of Language in Chinese Thought." In: Anthropopoetics: The Journal of Generative Anthropology 6.2. http://anthropoetics.ucla.edu/apo602/hurst/ (last visited 09.02.2018).

Ho, Ping-Ti (1998). "In Defense of Sinicization: A Rebuttal of Evelyn Rawski's 'Reenvisioning the Qing." In: The Journal of Asian Studies 57.I: I23-I55.

Hon, Tze-ki [Han Ziqi 韓子奇] (20I0). "From a Hierarchy in Time to a Hierarchy in Space: The Meanings of Sino-Babylonianism in Early Twentieth Century China." In: Modern China 36.3: 139-169.

Höhenrieder, Brigitte (2015). “Cultural Linguistics.” In: Rint P.E. Sybesma et al. (eds.): Encyclopedia of Chinese Language and Linguistics. http://dx.doi.org/I0.1163/2210-7363_ecll_ COM_00000059 (last visited 20.0I.2018).

Holz, Hans H. (1994). China im Kulturvergleich: Ein Beitrag zur philosophischen Komparatistik. Köln: Dinter \& Sant'Abbonmdio: Centro di Studi Filosofici.

Hösle, Vittorio (2013). "The Search for the Orient in German Idealism." In: Zeitschrift der Deutschen Morgenländischen Gesellschaft 163.2: 43I-454. 
Hourmant, François (1997). "La Chine ou le crépuscule du mythe révolutionnaire." In: Le désenchantement des clercs. Figures de l'intellectuel dans l'après-Mai 68. Rennes: Presses universitaires de Rennes: $17-55$.

Hsia, Adrian (1985 ed.). Deutsche Denker über China. Frankfurt: Insel.

Hsia, Adrian (2002). "Theistic and Non-Theistic Perspectives on Chinese Culture: Friedrich Schlegel, F.W.J. Schelling and Arthur Schopenhauer." In: International Symposium on the Bible and China, Furen Catholic University, Taipei, 5-8 January 2002. [Ms.]

Hu Shi 胡適 (1930 [1923]). “Lun di tian ji jiu ding shu 論帝天及九鼎書.” In: Gu Jiegang 顧頡剛 (ed.): Gushi bian 古史辨 Vol. IB. Beiping: Pushe 樸社: 199-200.

Huang Zunsheng 黄尊生 (1942). “Aiji xiangxingwen zhi zuzhi yu Zhongguo liushu zhi bijiao 埃 及象形文之組織及其與中國六書之比較.” In: Guoli Zhejiang Daxue Wenxueyuan Jikan 國 立浙江大學文学院集刊. 2: I-I5.

Huang Zunsheng 黄尊生 (2008). “Wo yu shijieyu yundong 我與世界語運動.” In: Guangzhou Wenshi Ziliao 廣州文史資料40. http://www.gzzxws.gov.cn/gzws/gzws/ml/40/200809/ t20080912_7492.htm (last visited 28.02.20I8).

Ineichen, Gustav (1987). "Historisches zum Begriff des Monosyllabismus im Chinesischen." In: Historiographia Linguistica I4.3: 265-282.

Itatsu Shichisaburô 板律七三郎 (I933). Aikan moji dōgen kō 埃漢文字同源考. Tōkyō: Oka Shoin 崗書院.

Itatsu Shichisaburō 板律七三郎 (1935). Aikan moji dōgen kō jūtei oyobi hoi 埃漢文字同源考重 項及補遺. Tōkyō: Oka Shoin 崗書院.

Jao, Tsung-i \& Vandermeersch, Léon (2006). "Les relations entre la Chine et le monde iranien dans l'Antiquité historiquement revisitées à la lumière des découverts archéologiques du dernier quart de siècle." In: Bulletin de l'École française d'Extrême-Orient 93: 207-245.

Ji Changming 季長明 \& Yang Junming 楊俊明 (1995). “Guoren dui gu Aiji xiangxing wenzi de zaoqi yanjiu 國人對古埃及象形文字的研究.” In: Shijie Lishi 世界歷史 2: 84-87.

Jin Lixin 金理新 (2002). Shanggu Hanyu yinxi 上古漢語音系. Hefei: Huangshan.

Johansson, Perry (2012). Saluting the Yellow Emperor. A Case of Swedish Sinography. Leiden: E.J. Brill.

Johansson, Perry (2016). “The Collaborative Dimension of Johan Gunnar Andersson's Search for a Western Origin of China." In: Bulletin of the History of Archaeology 26.I (II): I-8.

Jouanna, Jacques (1996). "Airs, eaux, lieux." In: Hippocrate, tome II. 2. Paris: Les Belles Lettres.

Kämper, Heidrun, Klosa, Annette \& Vietze, Oda (2008 eds.). Aufklärer, Sprachgelehrter, Didaktiker: Johann Christoph Adelung (I732-I806). Tübingen: Narr.

Kammerzell, Frank (1993). "Aristoteles, Derrida und die ägyptische Phonologie. Zu systematischen Verschiedenheiten von geschriebener und gesprochener Sprache.” In: [s.n.] Sesto Congresso Internazionale di Egittologia: Atti. Vol. 2. Turin: International Association of Egyptologists: 243-25I.

Karlgren, Bernhard (1920). "Le proto-chinois, langue flexionnelle." In: Journal Asiatique II.I5: $205-232$.

Kaske, Elisabeth (2008). The Politics of Language in Chinese Education, 1895-1919. Leiden: E.J. Brill.

Kennedy, George (I95I). “The Monosyllabic Myth.” In: Journal of the American Oriental Society 71.3: 16I-166.

Kern, Iso (1998). "Die Vermittlung chinesischer Philosophie in Europa." In: Jean-Pierre Schobinger (ed.): Die Philosophie des 17. Jahrhunderts. Vol. I: Allgemeine Themen, Iberische Halbinsel, Italien. Basel: Schwabe: 225-295.

Kim, Hyun Jin (2009). Ethnicity and Foreigners in Ancient Greece and China. London: Duckworth. 
Kircher, Athanasius (1667). China monumentis qua Sacris quà Profanis, Nec non variis naturae \& artis spectaculis, aliarumque rerum memorabilium argumentis illustrata .... Amstelodami: apud Jacobum à Meurs, in fossa vulgo de Keysersgracht.

Kircher, Athanasius (1652-1654). Oedipus Aegyptiacus, Hoc Est, Universalis Hieroglyphicae Veterum, Doctrinae temporum iniuria abolitae, Instauratio.... 4 pts, 3 Vols. Romae: Ex Typographia Vitalis Mascardi.

Kircher, Athanasius (1679). Turris Babel, sive archontolopia quod priscorum post diluvium hominum vita, more rerumque gestarum magnitudo, secundo turris fabrica civitatumque eocstructio, confusio linguorum, et inde gentium transmigrationis ... Amstelodami: Ex officina Janssonio-Waesbergiana.

Kittler, Friedrich (2014). Die Wabrheit der technischen Welt. Eassys zur Genealogie der Gegenwart. Berlin: Suhrkamp.

Klock-Fontanille, Isabelle (20I0). "La Chine illustrée d'Athanase Kircher (China monumentis illustrata, I667). La découverte des caractères chinois et son apport aux débats sur les écritures au XVIIe siècle.” In: Res Antiquae 7: I29-I44.

Kyong-McClain, Jeff (20I0). "Barbarian Caves or Han Tombs? Republican-Era Archaeology and the Reassertion of Han Presence in Ancient Sichuan." In: Twentieth-Century China 35.2: 4-24.

Lacan, Jacques (1956). "Fonction et champ de la parole et du langage en psychanalyse. (Rapport du Congrès de Rome tenu à l'Istituto di Psicologia della Universitá di Roma les 26 et 27 septembre 1953)." In: La psychanalyse I: 8I-I66.

Lacan, Jacques (1968-1969). Le séminaire de Jacques Lacan XVI: D’un autre à l'autre (texte établi par Jacques-Alain Miller). Paris: Édition du Seuil.

Lacan, Jacques (1980 [1959-60]). Le seminaire de Jacques Lacan VII: L'éthique de la psychanalyse (texte établi par Jacques-Alain Miller). Paris: Édition du Seuil.

Lacan, Jacques (1996). Écrits. Paris: Édition du Seuil.

Lackner, Michael (2008). "Ex Oriente Scientia? Reconsidering the Ideology of a Chinese Origin of Western Knowledge.” In: Asia Major (3rd ser.) 21.I: 183-200 (=Star Gazing, Firephasing, and Healing in China: Essays in Honor of Nathan Sivin).

Laermann, Klaus (1985). "Das rasende Gefasel der Gegenaufklärung. Dietmar Kamper als Symptom.” In: Merkur 433: 2II-330.

Laermann, Klaus (1986). "Lacancan and Derridada. Über die Frankolatrie in Kulturwissenschaften." In: Kursbuch 84: 34-43.

Lanselle, Rainier (20I0a). "La Chine des psychanalystes français." In: Études chinoises (hors-série): 313-324.

Lanselle, Rainier (20Iob). "Le sujet chinois dans la demande de la psychanalyse." In: Frédéric Wang (ed.): Le choix de la Chine d'aujourd'hui, entre la Tradition et l'Occident. Paris: Les Indes Savante: $17-37$.

Lee, Eun-Jeung (2003). “Anti-Europa.” In: id.: Die Geschichte der Rezeption des Konfuzianismus und der konfuzianischen Gesellschaft seit der frühen Aufklärung. Eine ideengeschichtliche Untersuchung unter besonderer Berücksichtigung der deutschen Entwicklung. Münster, Hamburg, London: Lit.

Lee, Yun Kuen (2002). "Building the Chronology of Early Chinese History." In: Asian Perspectives 4I.I: $15-42$.

Leibold, James (20II). "Filling in the Nation: The Spatial Trajectory of Prehistoric Archaeology in Twentieth-Century China." In: Brian Moloughney \& Peter Zarrow (eds.): Transforming History: The Making of a Modern Academic Discipline in Twentieth-Century China. Hong Kong: Chinese University Press. 
Leslie, Donald D. (1984). "Japhet in China." In: Journal of the American Oriental Society 104.3: 403-409.

Leung, Cécile (2002). Étienne Fourmont (1683-1745), Oriental and Chinese Languages in Eighteenth-century France. Leuven: Leuven University Press.

Lewis, Ricardo (2016). “Does Chinese Civilization Come from Ancient Egypt?” In: Foreign Policy (2 September). http://foreignpolicy.com/2016/og/o2/did-chinese-civilization-come-from-ancient-egypt-archeological-debate-at-heart-of-china-national-identity/ (last visited 08.05.20I7).

Li Fan 李帆 (2005). “Minzu zhuyi yu guoji rentong zhi jian-yi Liu Shipei de Zhongguo renzhong, wenming xilaishuo wei li 民族主義與國際認同之閒——以劉師培的中國人種、 文明西來說為.例.” In: Shixue Lilun Yanjiu 史學理論研究 4: 97-IO2.

Li Fan 李帆 (2008a). “Renzhong yu wenming: Lakeboli (Terrien de Lacouperie) xueshuo chuanru Zhongguo hou de ruogan wenti 人種与文明: 拉克伯里 (Terrien de Lacouperie) 學說傳入 中國後的若干問題.” In: Xinan Minzu Daxue Xuebao 西南民族大學學報 2: 3I-35.

Li Fan 李帆 (2008b). “Xifang jindai minzu guannian he 'Hua-Yi zhi bian' de jiaohui-zai lun Liu Shipei dui Lakeboli 'Zhongguo renzhong wenming xilaishuo' de jieshou yu chanfa 西方近代 民族觀念和「華夷之辨」的交匯——再論劉師培對拉客柏立「中國人種西來說」的接 受與闣發.” In: Beijing Shifan Daxue Xuebao 北京師範大學學報 2: 66-72.

Li, Feng (2009). Landscape and Power in Early China: The Crisis and Fall of the Western Zhou, 1045-77I BC. Cambridge: Cambridge University Press.

Li Xiaoqian 李孝遷 (2013). "Yuwai Hanxue yu gushibian yundong — jian yu Chen Xuran xiansheng shangque 域外漢學與古史辨運動——兼與陳學然先生商榷.” In: Zhonghua Wenshi Luncong 中華文史論垶 III.3: 265-3I2.

Li Xueqin 李學勤 (1994). Zouchu yigu shidai 走出疑古時代. Shenyang: Liaoning Daxue Chubanshe 遼寧大學出版社.

Li Xueqin 李學勤 (1995). “Dui 'Zouchu yigu shidai' de jidian shuoming 對《走出疑古時代》 的幾點說明.” In: Chuantong Wenhua yu Xiandai Wenhua 傳統文化與現代文化 6: 48-49.

Li Xueqin 李學勤 (2012). “Zouchu 'yigu shidai’ 走出「疑古時代」.” In: Zhongguo Wenhua 中 國文化 7: I-7.

Liang Yun 樑雲 (20I7). “Lun zaoqi Qin wenhua de laiyuan yu xingcheng 論早期秦文化的來源 與形成.” In: Kaogu Xuebao 考古學報 2: 149-174.

Li Yisan 李益三 (2008). “Shijieyu zhuanjia Huang Zunsheng jiaoshou 世界語專家黄尊生教 授” In: Guangzhou Wenshi Ziliao 廣州文史資料 40. http://www.gzzxws.gov.cn/gzws/gzws/ ml/40/200809/t20080912_7490_2.htm (last visited 22.02.2018).

Lin Yun 林澐 (2007). “Zhen gai zouchu yigu shidai ma? - Dui dangqian Zhongguo gudianxue quxiang de kanfa 真該走出疑古時代嗎? ——對當前中國古典學取向的看法.” In: Shixue Jikan 史學季刊3.3: 3-25.

Liu Fu 劉復 (1930 [1926]). “'Di’ yu 'tian’「帝」與「天」.” In: Gu Jiegang 顧頡剛 (ed.): Gushi bian 古史辨. Vol. 2A. Beiping: Pushe 樸社 1930: 20-27.

Liu Qiyu 劉起鈺 (1995). “Guanyu 'Zouchu yigu shidai’ wenti 關於「走出疑古時代」問題.” In: Chuantong Wenhua yu Xiandai Wenhua 傳統文化與現代文化 4: 22-28.

Lo, Alexander (1994). Hegel's Interpretation of Chinese History. M.A. thesis (unpublished). Hamilton: McMaster University. https://macsphere.mcmaster.ca/bitstream/II375/13948/I/ fulltext.pdf (last visited 22.I2.2017).

Lu, Mingjun (2015). The Chinese Impact upon English Renaissance Literature. A Globalization and Liberal Cosmopolitan Apporach to Donne and Milton. Farnham: Ashgate.

Lu, Ya-chuan [路亞娟] (2010). Une autre voie pour les Chinois ou: Comment la psychanalyse pourrait-elle s'écrire dans le monde chinois. Thèse doctorale, Université Paris VIII (Vincennes). 
http://doczz.fr/doc/682082/une-autre-voie-pour-les-chinois-ou-comment-la-psychanalyse (last visited 2I.I2.20I7).

Lubec, G. et al. (1993). "Use of Silk in Ancient Egypt." In: Nature 362: 25.

Luca, Dinu (2016). The Chinese Language in European Texts. The Early Period. New York: Palgrave Macmillan.

Lundbæk, Knud (1986). T. S. Bayer (I694-1738), Pioneer Sinologist. London etc. Curzon Press.

Lundbæk, Knud (1991). Joseph de Prémare (I666-1736), S.J.: Chinese Philology and Figurism. Aarhus: Aarhus University Press.

Ma Chengyuan 馬承源 (1983). “Niao chong shu lungao 鳥蟲書論稿.” In: Guwenzi Yanjiu 古文 字研究 IO: 137-176.

Maas, Utz (1986). “'Die Schrift ist ein Zeichen für das, was in dem Gesprochenen ist.' Zur Frühgeschichte der Sprachwissenschaftlichen Schriftauffassung: das aristotelische und das nacharistotelische) Schriftverständnis.” In: Kodikas/Code 9.3-4: 247-292.

Maat, Jaap (2004). Philosophical Languages in the Seventeenth Century: Dalgarno, Wilkins, Leibniz. Dordrecht, Boston, London: Kluwer Academic.

Mair, Victor H. (1990). [The] File [on the Cosmic] Track [and Individual] Dough[Tiness]. Introduction and Notes for a Translation of the Ma-Wang-tui Manuscripts of the Lao Tzu [Old Master]. Philadelphia: University of Pennsylvania. (Sino-Platonic Papers 20).

Martinet, André (1955). Économie des changements phonétiques. Traité de phonologie diachronique. Bern: Francke.

Maspéro, Henri (1930). "Préfixes et derivation en chinois archaïque." In: Mémoires de la Société Linguistique de Paris 23: 313-327.

Matten, Marc (2009). Die Grenzen des Chinesischen - Nationale Identitätsstiftung im China des 20. Jahrhunderts. Wiesbaden: O. Harrassowitz.

McDavid, Raven I. (1990). "Linguistic Geography and Language Change.” In: Edgar C. Polomé (ed.): Research Guide on Language Change. Berlin \& New York: Mouton de Gruyter: I6I-I74.

McWhorter, John (2016). The Language Hoax. New York: Oxford University Press.

Merkel, Franz R. (1942). "Herder und Hegel über China." In: Sinica I7: 5-26.

Metcalf, George J. (1984). "Adelung Discovers the Languages of Asia.” In: Histoire, Épistémologie, Langage 6.2: IOI-II5.

Metcalf, George J. (2013). On Language Diversity and Relationship from Bibliander to Adelung. Toon Van Hal \& Raf van Rooy (eds., introd.). Amsterdam: John Benjamins.

Michaud, Alexis (20I2). "Monosyllabicization: Patterns of Evolution in Asian Languages." In: Nicole Nau, Thomas Stolz \& Cornelia Stroh (eds.). Monosyllables: From Phonology to Typology. Berlin: Akademie Verlag: II5-I30.

Moloughney, Brian (20II). "Myth and the Making of History: Gu Jiegang and the Gushi bian Debates." In: B. Moloughney \& P. Zarrow (eds.): Transforming History: The Making of a Modern Academic Discipline in Twentieth-Century China. Hong Kong: Chinese University Press: 24I-270.

Morenz, Ludwig (2008). Sinn und Spiel der Zeichen: visuelle Poesie im Alten Ägypten. Köln: Böhlau. Müller-Saini, Gotelind \& Benton, Gregor (2006). "Esperanto and Chinese Anarchism, 19071920: The Translation from Diaspora to Homeland.” In: Language Problems and Language Planning 30.I: $45-55$.

Münkler, Marina (2000). Erfahrung des Fremden. Die Beschreibung Ostasiens in den Augenzeugenberichten des I3. und I4. Jahrhunderts. Berlin: Akademie Verlag.

Naborn, Rob (1995). "Becanus' Etymological Methods." In: Voortgang, Jaarboek voor de Neerlandistiek 15: 79-86. 
Nickel, Lukas (2013). "The First Emperor and Sculpture in China." In: Bulletin of the School of Oriental and African Studies 76.3: 413-447.

Nyman, Martti (1986). “Is the Paradigm Economy Principle relevant?" In: Journal of Linguistics 23: 25I-267.

Pan Wuyun 潘悟雲 (1998). “Han-Zangyu de ciyao yinjie 漢藏語的次要音節.” In: Pan Wuyun \& Shi Feng 石峰 (eds.): Zhongguo yuyanxue de xin tuozhan 中國語言學的新拓展. Hong Kong: City University of Hong Kong Press: I26-I47.

Paquet, Philippe (2016). Simon Leys. Navigateur entre les mondes. Paris: Gallimard.

Parret, Herman (1975): "Grammatology and Linguistics. A Note on Derrida's Interpretation of Linguistic Theories." In: Poetics 4.I: I07-I27.

Pauthier, Jean Pierre G. (I83I). Mémoire sur l'origine et la propagation de la doctrine du tao, fondée par Lao-Tseu: traduit du chinois et accompagné d'un commentaire tiré des livres sanskrits et du Tao-te-king de Lao-tseu, établissant la conformité de certaines opinions philosophiques de la Chine et de l'Inde, avec un dessin chinois: suivi de deux oupanichads des Védas, avec le texte sanskrit et persan. Paris: Libraire Orientale de Dondey-Dupré.

Pauthier, Jean Pierre G. (1837a). Chine ou description historique, géographique et littéraire de ce vaste empire, d'après des documents chinois. Paris: Didot Fr.

Pauthier, Jean Pierre G. (I837b). Le Ta hio, ou La grande étude, le premier des quatres livres de philosophie morale et politique de la Chine; ouvrage de Khoung-Fou-tseu [Confucius] et de son disciple Thseng-Tseu; tr. en français avec une version latine et le texte chinois en regard, accompagné du commentaire complet de Tchou-Hi, et de notes tirées de divers autres commentateurs chinois, Paris: F. Didot Fr.

Pauthier, Jean Pierre G. (I84I). Confucius et Mencius: les quatre livres de philosphie morale et politique de la Chine. Paris: Charpentier.

Pauthier, Jean Pierre G. (1842a). Les livres sacrés de l'Orient, comprenant: le Chou-king ou le Livre par excellence; les Sse-chou ou les Quatre livres moraux de Confucius et de ses disciples; les Lois de Manou; le Koran de Mahomet. Paris: Société du Panthéon Littéraire.

Pauthier, Jean Pierre G. (1842b). Sinico-Aegyptiaca. Essai sur l'origine et la formation similaire des écritures figuratives chinoise et égyptienne, composé principalement d'après les écrivains indigènes, traduits pour la première fois dans une langue européenne. Paris: Didot Fr.

Pauthier, Jean Pierr G. (I872). Hymnes sanscrits, persans, égyptiens, assyriens et chinois; Chi-king, ou Livre des vers. Paris: Maisonneuve.

Pellery, Roberto (1992). "La Cina e il nuovo mondo. Il mito dell'ideografia nella lingua delle Indie". In: Belfagor 47.5: 507-522.

Penny, Benjamin (2007). "More than one Adam? Revelation and Philology in NineteenthCentury China." In: Humanities Research I4.I: 3I-50.

Pfister, Louis (1934). Notices biographiques et bibliographiques sur les Jésuites de l'anciene mission de Chine. I552-I773. Vol. 2: XVIIIe siècle. Shanghai: Mission Catholique.

Pines, Yuri (2005): "Beasts or Humans: Pre-Imperial Origins of Sino-Barbarian Dichotomy." In R. Amitai \& M. Biran (eds.): Mongols, Turks, and Others: Eurasian Nomads and the Sedentary World. Leiden: E.J. Brill: 59-IO2.

Plank, Frans (2000-). Das grammatische Raritätenkabinett - A Leisurely Collection to Entertain and Instruct. https://typo.uni-konstanz.de/rara/ (last visited 21.I2.20I7).

Porret, Philippe (2008). La Chine de la psychanalyse. Paris: Campagne Première.

Potts, Chris (2002). "Comparative Economy Conditions in Natural Language Syntax." Ms. University of California at Santa Cruz. https://pdfs.semanticscholar.org/13d4/dcd3b4a 4 ef98f7 fao9887b7497345dbidff5.pdf (last visited 22.12.2017). 
Pulleyblank, Edwin G. (1962). “The Consonantal System of Old Chinese.” In: Asia Major 9: 58-I44, 206-265.

Ramsey, Rachel (198I). "China and the Ideal of Order in John Webb's an 'Historical Essay...." In: Journal of the History of Ideas 62.3: 483-503.

Rao Zongyi 饒宗頣 (1983). “'Tianwen’ wenti yuanliu - 'fawen’ wenxue zhi tantao 《天問》文體 的源流「發問」文學之探討.” In: id.: Xuantáng jilin 選堂集林. Vol. I. Taibei: Mingwen 明 文: 83-108.

Reichert, Folker (1992). Begegnungen mit China: die Entdeckung Ostasiens im Mittelalter. Sigmaringen: Thorbecke.

Rémusat, Abelo de (I813). "Utrum Lingua Sinica sit vere monosyllabica? Disputatio philologica, in qua de Grammatica Sinica obiter agitur." In: Graf Wenceslaus Rzewusky \& "Eine Gesellschaft von Liebhabern" (eds.): Fundgruben des Orients / Mines de l'Orient. Vol. 3. Wien: Anton Schmid \& K.K. Privil: 279-296.

Rémusat, Jean-Pierre Abel de (I8I4). "Considérations sur la nature monosyllabique communément attribuée à la langue chinoise." L.A.M. Bourgeat (transl.). In: Mercure de France. Journal Littéraire et Politique 59: 96-106.

Richter, Mathias (2017). "Punctuation, Premodern." In: Rint P.E. Sybesma et al. (eds.): Encyclopedia of Chinese Language and Linguistics. Vol. 4. Leiden: E.J. Brill: 46-55.

Richter, Ursula (1992). Zweifel am Altertum: Gu Jiegang und die Diskussion über Chinas alte Geschichte als Konsequenz der "neuen Kulturbewegung” ca. I9I5-I923. Stuttgart: Steiner.

Rochemonteix, Camille de (1915). Joseph Amiot et les derniers survivants de la Mission française à Pékin: (1750-1795): nombreux documents inéd. avec carte. Paris: Picard.

Roelcke, Thomas (2017). "Asiatische Sprachen im deutschen Sprachdenken des Barock und der Aufklärung." In: Glottotheory 8.2: 217-235.

Roetz, Heiner (1984). Mensch und Natur im alten China. Zum Subjekt-Objekt-Gegensatz in der klassischen chinesischen Philosophie. Zugleich eine Kritik des Klischees vom chinesischen Universismus. Frankfurt: Peter Lang.

Roetz, Heiner (1992). Die chinesische Ethik der Achsenzeit: eine Rekonstruktion unter dem Aspekt des Durchbruchs zu postkonventionellem Denken. Frankfurt am Main: Suhrkamp.

Roetz, Heiner (1995). "Die chinesische Sprache und das chinesische Denken. Positionen einer Debatte." In: Bochumer Jahrbuch zur Ostasienforschung 30 (Wolfgang Behr \& Heiner Roetz [eds.]: Sprache und Denken in China und Japan): 9-37.

Roetz, Heiner (2005). "Philosophy in China? Notes on a Debate." In: Extrême-Orient, Extrême Occident 27: 49-65.

Roetz, Heiner (2013). "The Influence of Foreign Knowledge on Eighteenth Century European Secularism.” In: Marion Eggert \& Lucian Hölscher (eds.): Religions and Secularity. Transformations and Transfers of Religious Discourses in Europe and Asia. Leiden, Boston: E.J. Brill: 9-33.

Rong Geng 容庚 (1964). “Niao shu kao 鳥書考.” In: Zhongshan Daxue Xuebao 中山大學學報 I: $75-\mathrm{II} 3$.

Roudinesco, Elisabeth (1994). Histoire de la psychanalyse en France 2, 1925-1985. Paris: Fayard.

Roudinesco, Elisabeth (1997). Jacques Lacan: Outline of a Life, History of a System of Thought. New York: Columbia University Press.

Rowbotham, A. H. (1956). “The Jesuit Figurists and Eighteenth Century Religious Thought.” In: Journal of the History of Ideas 17: 47I-485.

Rusk, Bruce (2007). "Old Scripts, New Actors: European Encounters with Chinese Writing, I550- I700.” In: East Asian Science, Technology and Medicine 26: 68-116. 
Rybatzki, Volker (2006). Die Personennamen und Titel der mittelmongolischen Dokumente. Eine lexikalische Untersuchung. Helsinki: Yliopistopaino Oy.

Sagart, Laurent (1999). The Roots of Old Chinese. Amsterdam: John Benjamins.

Salmons, Joseph \& Zhuang, Huibin (2018). "The Diachrony of East Asian Prosodic Templates." In: Linguistics 56.3: 549-580.

Sánchez, Alonso (1583). Relación breve de la jornada quel P. Alonso Sánchez dela Compañia de Jesús hizo por horden y parezer del SR. D. Gonzalo Ronquillo de Peñalosa, governador de Philipinas, y del Sr. obispo y oficiales de S.M. desde la Isla de Luzón y ciudad de Manila a los Reynos de la China. Manila, Ms. Pompeu Fabra, Barcelona transcr. \& ed. by Manel Ollé Rodríguez. https://www.upf.edu/asia/projectes/che/sı6/sanchez2.htm (last visited 20.12.20I7).

Saussure, Ferdinand, Bally, Charles \& Sechehaye, Albert (1916 eds.). Cours de linguistique générale. Lausanne \& Paris: Payot.

Saussure, Ferdinand de (2005 [1910-19II]). "Linguistique générale (Cours de M’ le Professeur de Saussure) Semestre d'hiver I9I0-I9II." In: Émile Constantin (ed.): Cahiers Ferdinand de Saussure 58: 82-290.

Saussy, Haun (1993). The Problem of a Chinese Aesthetic. Stanford: Stanford University Press.

Saussy, Haun (200I). Great Walls of Discourse and Other Adventures in Cultural China. Cambridge: Harvard University Press.

Sautman, Barry S. (200I). "Peking Man and the Politics of Paleoanthropological Nationalism in China." In: The Journal of Asian Studies 6o.I: 95-124.

Schelling, Friedrich W.J. von (1856). Philosophie der Mythologie. In: Carl F.A. Schelling (ed.): Sämtliche Werke. Vol. I.2. Stuttgart und Augsburg: J.G. Cotta.

Schickel, Joachim (1976 [1968]). Große Mauer, Große Methode. Annäherungen an China. Stuttgart: Klett, repr. Frankfurt: Suhrkamp.

Schickel, Joachim (1970). "Hegels China - Chinas Hegel.” In: Oskar Negt (ed.): Aktualität und Folgen der Philosophie Hegels. Frankfurt am Main: Suhrkamp: I87-198.

Schott, Wilhelm (1860). Altajische Studien oder Untersuchungen auf dem Gebiete der AltaiSprachen. Berlin: Königl. Akademie der Wissenschaften.

Schreyer, Rüdiger (1992). The European Discovery of Chinese (I550-I6I5), or: The Mystery of Chinese Unveiled. Amsterdam: Stichting Neerlandistiek VU.

Schubert, Charlotte (2000). "Konstruktionsprinzipien des Weltbildes: Die Hippokratische Schrift De aeribus und die Suche nach der Mitte der Welt." In: Medizinhistorisches Journal 35.3-4: 20I- 218.

Serrano, Richard (1996). Berbers, Buddhists, and Bibelots: Appropriation of Alien Traditions by French, Chinese, Arab, and Francophone Poets. Unpublished PhD Diss., Berkeley: University of California.

Serrano, Richard (1997). "Lacan's Oriental Language of the Unconscious." In: SubStance 3.84: 90-106.

Shao Wangping 郡望平 \& Mo Runxian 莫潤先 (1989). “Waxiliyefu Zhongguo wenming de qiyuan wenti 瓦西里耶夫《中國文明的起源問題》.” In: Kaogu 考古 I2: II32-II4O.

Shi Dangshe 史黨社 (2015). “Xinchu kaogu, wenzi ziliao yu Qinren zaoqi lishi 新出考古、文字 資料與秦人早期歷史.” In: Guoxue Xuekan 國學學刊 4: I8-27.

Singer, Thomas C. (1989). "Hieroglyphs, Real Characters, and the Idea of Natural Language in English Seventeenth-Century Thought." In: Journal of the History of Ideas 50.I: 49-70.

Smith, Richard J. (2017). "Albert Terrien de Lacouperie's (1845-I894) Translation of the Yijing and the Debates in Europe and Asia over the "Western Origins of Chinese Civilization."' In: Journal of Translation Studies, n.s., I.I: 207-240. 
Spence, Jonathan (1988). "Matteo Ricci and the Ascent to Peking." In: Charles E. Ronan \& Bonnie Oh (eds.): East Meets West: The Jesuits in China, 1582-1773. Chicago: Loyola University Press: 3-I8; repr. In: Jonathan D. Spence: Chinese Roundabout. Essays in History and Culture. New York: W.W. Norton \& Comp 1992: 37-49.

Spitzel, Gottlieb (1660). De re literaria Sinensium commentarius, in quo scripturae pariter ac philosophiae Sinicae specimina exhibentur, et cum aliarum gentium, praesertim Aegyptiorum, Graecorum, et Indorum reliquorum literis atque placitis conferuntur. Lugdunum Batavorum: Ex Officina Petri Hackii. [Digital version of Bavarian State Library, Munich, H.p.lit. 355]. http://reader.digitale-sammlungen.de/de/fsi/object/display/bsbioı78702_00005.htm (last visited 22.12.2017).

Spivak, Gayatri (1976). "Translator's Preface." In: Jacques Derrida (ed.): Of Grammatology. Baltimore: Johns Hopkins University Press: ix-lxxxv.

Sproat, Richard (2017). "A Computational Model of the Discovery of Writing." In: Written Language and Literacy 20.2: 194-226.

Stassen, Leon (2000). “AND-Languages and WITH-Languages." In: Linguistic Typology 4: I- 54.

Steinthal, Heymann (I852). Die Entwickelung der Schrift, nebst einem offenen Sendschreiben an Prof. Pott. Berlin: F. Dümmler.

Steinthal, Heymann (1999 [I854]). "Zur Vergleichenden Erforschung der chinesischen Sprache" (ed. by Jerrold A. Edmondson). In: Joan Leopold (ed.): Prix Volney Essay Series. Vol. 3: Contributions to Comparative Indo-European, African, and Chinese Linguistics: Max Müller and Steinthal. Dordrecht: Kluwer Academic Publishers 1999: 415-498.

Stetter, Christian (1997). Schrift und Sprache. Frankfurt am Main: Suhrkamp.

Stockhammer, Robert (2014). Grammatik. Wissen und Macht in der Geschichte einer sprachlichen Institution. Berlin: Suhrkamp.

Sun Jiang 孫江 (2010). “Lakuboli 'Zhongguo wenming xilaishuo' zai Dongya de chuanbu yu wenben bijiao 拉克伯里「中國文明西來說」在東亞的傳布與文本之比較.” In: Lishi Yanjiu 歷史研究 I: 116-I37.

Sun, Wei-dong et al. (2016). "Origin of the Mysterious Yin-Shang Bronzes in China Indicated by Lead Isotopes." In: Scientific Reports 6: I-9.

Svobodová, Kateřina (2018). Iranian and Hellenistic Architectural Elements in Chinese Art. Philadelphia: Department of East Asian Languages and Civilizations, University of Pennsylvania. (SinoPlatonic Papers 274).

Szczesniak, Boleslaw (1952). "The Origin of the Chinese Language According to Athanasius Kircher's Theory." In: Journal of the American Oriental Society 72.I: 2I-29.

Terol Rojo, Gabriel (20I5). La epistemología subjetiva del Daoismo. Unpublished PhD Diss., Universitat de Valencia.

Terrien de Lacouperie, Albert (I889). "Le non-monosyllabisme du Chinois antique. L'écart entre les langues écrite et parlée d'aujourdhui et l'histoire de la langue écrite.” In: Le Muséon 8: 247-26I.

Terrien de Lacouperie, Albert (1894). Western Origin of the Early Chinese Civilisation from 2300 B.C. to 200 A.D., or, Chapters on the Elements Derived from the Old Civilisations of West Asia in the Formation of the Ancient Chinese Culture. London: Asher \& Co.

Thouard, Denis (1999 eds.). Lettres édifiantes et curieuses sur la langue chinoise: un débat philosophico-grammatical entre Wilhelm von Humboldt et Jean-Pierre Abel-Rémusat (I82I-I83I avec une correspondance inédite de Humboldt (I824-I83I) présentée par Jean Rousseau, Humboldt/AbelRémusat (I82I-I83I). Villeneuve-d'Ascq: Presses universitaires du Septentrion.

Tong, Q.S. (20IO). "Global Modernity and Linguistic Universality: The Invention of Modern Chinese Language.” In: Eighteenth-Century Studies 43.3: 325-339. 
Tscharner, Eduard von (1939). China in der deutschen Dichtung bis zur Klassik. München: Ernst Reinhardt.

Tsui, Wai (2009). “The Expressions of Self in Wang Tao's 王蓞 Manyou Suilu 漫遊隨錄.” In: Zhongguo Wenhua Yanjiusuo Xuebao 中國文化研究所學報 / Journal of Chinese Studies 49: 277-302.

Türcke, Christoph (2005). Vom Kainszeichen zum genetischen Code: Kritische Theorie der Schrift. München: C. H. Beck.

Tuyl, Charles D. van (1987 transl.). China illustrata: With Sacred and Secular Monuments, Various Spectacles of Nature and Art and other Memorabilia. Bloomington, Ind.: Indiana University Research Institute for Inner Asian Studies.

Uehlinger, Christoph (1990). Weltreich und "eine Rede": eine neue Deutung der sogenannten Turmbauerzählung (Gen II, I-q). Freiburg: Vandenhoeck \& Ruprecht.

Uehlinger, Christioph (20I4). "Babel, Pfingsten - und Rassentheorien: religiöse Bewertungen von Sprachenvielfalt und ihren Nachwirkungen." In: Elvira Glaser et al. (eds.): Sprache(n) verstehen. Zürich: vdf Hochschulverlag: I5I-I78.

Vasil'ev, Leonid S. (1976). Problemy genezisa kitajskoj civilizacii. Formirovanie osnov material'noj kul'tury i ètnosa. Moscow: Nauka.

Vasil'ev, Leonid S. (1983a). Problemy genezisa kitajskogo gosudarstva. Moscow: Nauka.

Vasil'ev, Leonid S. (1983b). Problemy genezisa kitajskoj mysli. Formirovanie osnov mirovozzrenia i mentaliteta. Moscow: Nauka.

Vicentini, Alessandra (2003). "The Economy Principle in Language. Notes and Observations from Early Modern English Grammars." In: Mots - Palabras - Words 3: 37-57.

Wang, Haili (2015). "Chinese Approaches to Egyptian Hieroglyphs: liushu and bushou." In: Zeitschrift der Deutschen Morgenländischen Gesellschaft 165.2: 279-302.

Wang, Mingming (2014). The West as the Other. A Genealogy of Chinese Occidenatlism. Hong Kong: The Chinese University Press.

Wang Xuedian 王學典 (20IO ed.). 'Yigu' yu 'Zouchu yigu'「疑古」與「走出疑古」. Beijing: Shangwu Yinshuguan 商務印書館.

Watters, Thomas (I889). Essays on the Chinese Language. Shanghai: Presbyterian Mission Press.

Webb, John (1669). An Historical Essay Endeavoring a Probability that the Language of the Empire of China is the Primitive Language. London: Brook. [Digital version of Bayrische Staatsbibliothek, Munich] http://www.mdz-nbn-resolving.de/urn/resolver.pl?urn=urn:nbn:de:bvb:I2-bsbio583232-4 (last visited 2I.I2.20I7).

West, Martin L. (1997): The East Face of Helicon: West Asiatic Elements in Greek Poetry and Myth. Oxford: Clarendon Press.

Weststijn, Thijs (2007). "Spinoza sinicus. An Asian Paragraph in the History of the Radical Enlightenment." In: Journal of the History of Ideas 6.4: 537-56I.

Wittfogel, Karl A. (I93I). "Hegel über China." In: Unter dem Banner des Marxismus 5.3: 346-362.

Wolin, Richard (2012). The Wind from the East: French Intellectuals, the Cultural Revolution, and the Legacy of the Ig60s. Princeton: Princeton University Press.

Won, Kenn [=Huang Juansheng 黄涓生] (1926). Origine et évolution de l'écriture hiéroglyphique et de l'écriture chinoise. Paris: P. Geuthner.

Wu Fuxiang 吳福祥 (2017). “Cong quyu yuyanxue dao quyu leixingxue 從區域語言學到區域 類型學.” In: Minzu Yuwen 民族語文 (6): 3-19.

Yan Zhibin 嚴志斌 (200I). “Niaoshu gouxing jianlun 鳥書構型簡論.” In: Hua-Xia Kaogu 華 夏考古 I: 94-97. 
Yang Jianfang 楊建芳 (1977). “'Yangshao wenhua xilaishuo' jiudiao de chongtan-ping Waxiliyefu de liang pian fan-Hua wenzhang「仰韶文化西來說」舊調的重彈一一評瓦西里耶夫的 兩篇反華文章.” In: Sichuan Daxue Xuebao 四川大學學報 I: I29-I34.

Yang Sixin 楊思新 (1999). “Dui 'Zhongguo wenhua xilaishuo' de lishi kaocha 對「中國文化西 來說」的歷史考察.” In: Huaiyang Shifan Xueyuan Xuebao 淮陽師範學院學報 2I.4: IOI-IO4.

Yang Sixin 楊思新 (2003). “Lakeboli de 'Zhongguo wenhua xilaishuo' ji qi zai jindai Zhongguo de fanxiang 拉克伯里的「中國文化西來說」及其在近代中國的反響.” In: Zhonghua Wenbua Luntan 中華文化論壇 3: I4I-I46.

Yang Xue 楊雪 (2OI2). “Zhongguo wenming zhong de Aiji yinxiang 中國文明中的埃及影響.” In: Guangming Ribao 光明日報 (I4 may) http://theory.people.com.cn/GB/I78803Ir.html (last visited 02.02.2018).

Yen, Hsiao-pei (20I4). "Evolutionary Asiacentrism, Peking Man, and the Origins of Sinocentric Ethno-Nationalism." In: Journal of the History of Biology 47: 585-625.

Yong, Jichun 雍際春 (20II). “Jin bainian lai Qingren zuyuan wenti yanjiu zongshu 近百年來秦 人族源問題研究綜述.” In: Shehui Kexue Zhanxian 社會科學戰線 9: 109-117.

Yu Taishan 余太山 (2002). "Liang-Han Wei-Jin Nanbeichao zhengshi 'Xiyu zhuan' suojian xiyu zhuguo wuchan 兩漢魏晉南北朝正史「西域傳」所見西域諸國物產.” In: Guangzhi 光知 et al. (eds.): Yifen ji: Zhang Zhenglang xiansheng jiushi huadan jinian wenji 捍芬集: 张政烺先 生九十華誕紀念文集. Beijing: Shehui Kexue Chubanshe 社會科學: 437-453.

Zesen, Philipp von (1980 [165I]). Rosen-Mând. In: Ferdinand von Ingen et al. (eds.): Philipp von Zesen. Sämtliche Werke. Vol. II. Berlin \& New York: De Gruyter.

Zhaluo 扎洛 (2013) “'Zhongguo renzhong xilaishuo' yu Qingmo de Han-Zang tongyuanlun 中 國人種西來說”與清末的漢藏同源論.” In: Qinghai Minzu Yanjiu 青海民族研究 4: I17-I23.

Zhang Zhenglang 張政烺 (1980). "Shi shi Zhou-chu qingtongqi mingwen zhong de Yi gua. 試 釋周初青銅器銘文中的易卦.” In: Kaogu Xuebao 考古學報 4：3-I5. (engl. transl. by E.L Shaughnessy, Jeffrey Ching et al. available in Early China 6 (1980-8I): 80-96).

Zhao Dan 趙丹 (20II). “Zhang Taiyan 'Yi zi chong yin shuo' chu tan 章太炎「一字重音說」初 探.” In: Xiandai Yuwen 現代語文 I2: 9-IO.

Zhou, Jixu [周及徐] (2005). “Old Chinese '*tees' and Proto-Indo-European '*deus:' Similarity in Religious Ideas and a Common Source in Linguistics.” Philadelphia: University of Pennsylvania. (Sino-Platonic Papers 167).

Zhou Shucan 周書燦 (2009). “Muqian gushi yanjiu zhong de 'xingu', 'fugu' qiingxiang pingxi 目前 古史研究中的“信古”、“復古”傾㗽評析.” In: Shehui Kexue Pinglun 社會科學評論 2: 5-I5.

Zhou Shucan 周書燦 (2016). "Yangshao wenhua xilaishuo de xingcheng ji lunzheng-xue-shushi shiye xia de kaocha” 仰韶文化西來說的形成及論爭——學術史視野下的考察. In: Hebei Shifan Daxue Xuebao 河北師范大學學報 4: 5-I2. 